\title{
Curriculum assessment in the Division of Sociology and Anthropology at West Virginia University
}

Jennifer Luise Mitchell

West Virginia University

Follow this and additional works at: https://researchrepository.wvu.edu/etd

\section{Recommended Citation}

Mitchell, Jennifer Luise, "Curriculum assessment in the Division of Sociology and Anthropology at West Virginia University" (2009). Graduate Theses, Dissertations, and Problem Reports. 822.

https://researchrepository.wvu.edu/etd/822

This Thesis is protected by copyright and/or related rights. It has been brought to you by the The Research Repository @ WVU with permission from the rights-holder(s). You are free to use this Thesis in any way that is permitted by the copyright and related rights legislation that applies to your use. For other uses you must obtain permission from the rights-holder(s) directly, unless additional rights are indicated by a Creative Commons license in the record and/ or on the work itself. This Thesis has been accepted for inclusion in WVU Graduate Theses, Dissertations, and Problem Reports collection by an authorized administrator of The Research Repository @ WVU. For more information, please contact researchrepository@mail.wvu.edu. 
Curriculum Assessment in the Division of Sociology and Anthropology at West Virginia University

Jennifer Luise Mitchell

Thesis submitted to the Eberly College of Arts and Sciences at West Virginia University in partial fulfillment of requirements for the degree of

\author{
Master of Arts \\ in \\ Sociology \\ Area of Emphasis in \\ Applied Social Research \\ Jennifer Steele, Ph.D., Chair \\ Ronald Althouse, Ph.D. \\ Melissa Latimer, Ph.D.
}

Division of Sociology and Anthropology

Morgantown, West Virginia

2009

Keywords: Assessment, Sociology

Copyright 2009 Jennifer Mitchell 


\author{
Abstract \\ Curriculum Assessment in the Division of Sociology and Anthropology \\ at West Virginia University \\ Jennifer Mitchell
}

Program evaluation is essential for any organization to be successful. The purpose of this thesis is to contribute to the curriculum assessment in Division of Sociology and Anthropology and to make recommendations for next steps. Graduating senior surveys from 66 seniors during the Spring 2008 semester and transcripts from 504 students that graduated from the department between May 2004 through May 2008 were analyzed. Results suggest that department needs to improve upon advising, the coordination of internships, and the statistics requirement for their students. Through careful planning the department can improve upon these areas. To move forward with assessment in the future the department should consider using the capstone courses and possibly the use of subject tests as direct measures of student learning. 


\section{Table of Contents}

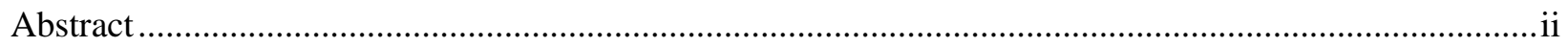

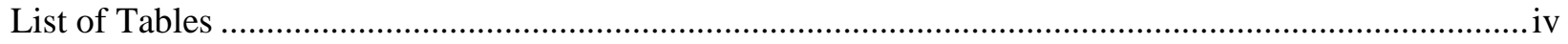

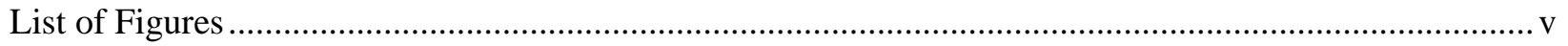

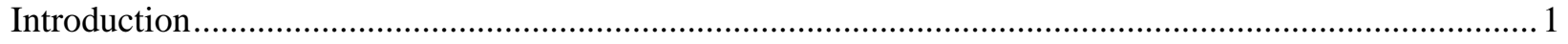

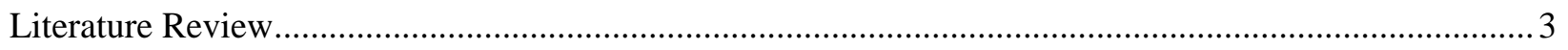

Assessment Approaches and Methods …............................................................................................

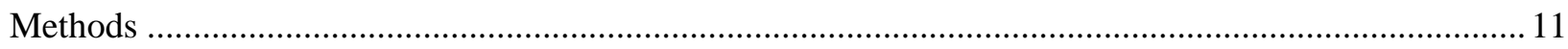

Assessment in the Division of Sociology and Anthropology .......................................................... 11

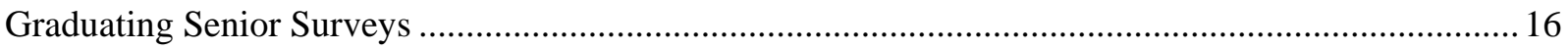

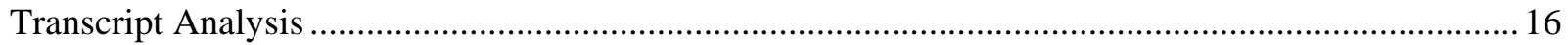

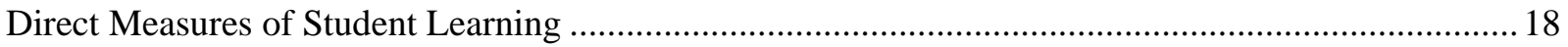

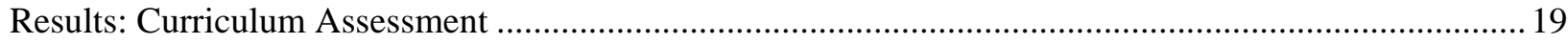

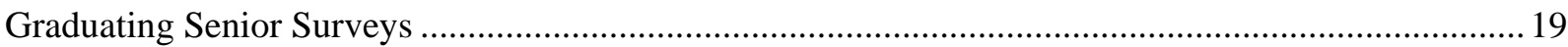

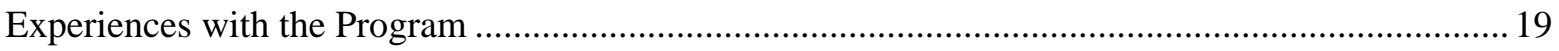

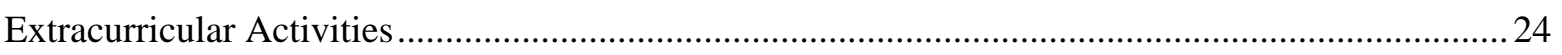

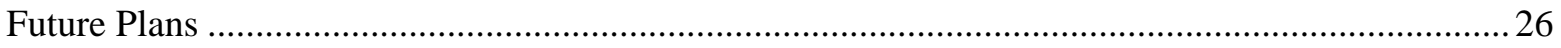

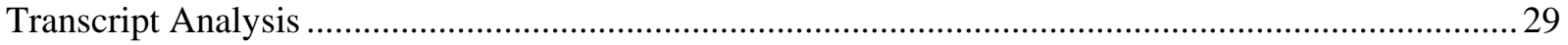

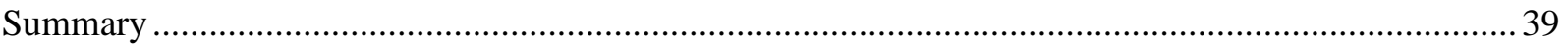

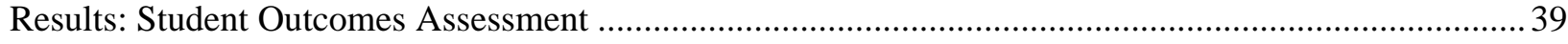

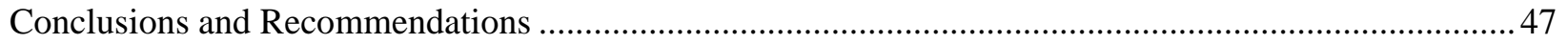

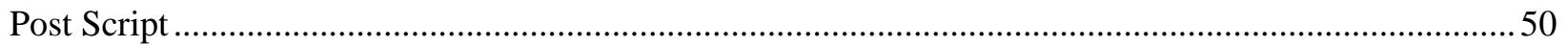

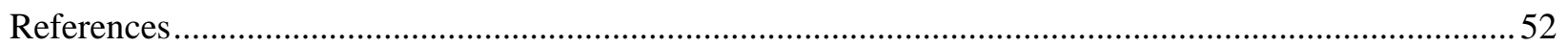

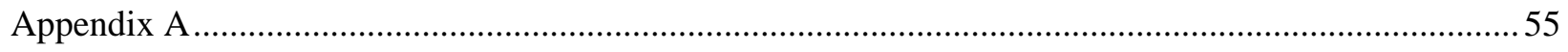

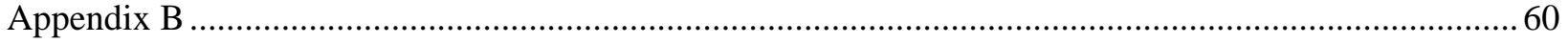




\section{List of Tables}

TABLE 1: REQUIREMENTS FOR ADMISSION AND COMPLETION OF MAJOR...............................................................20

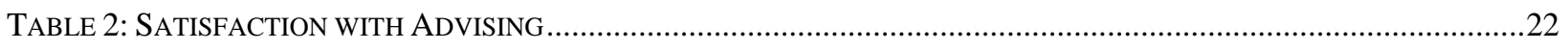

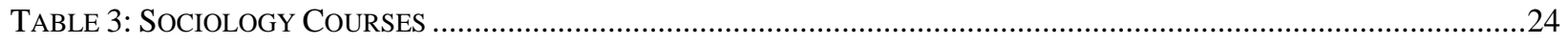

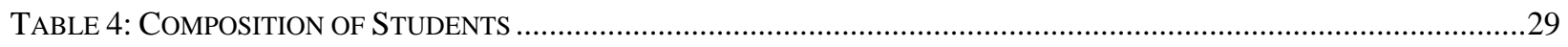

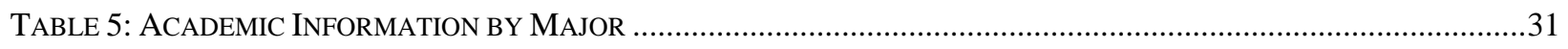

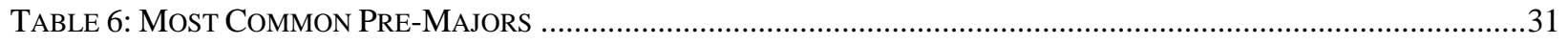

TABLE 7: NUMBER OF PRE-MAJORS DeClARED ..................................................................................................31

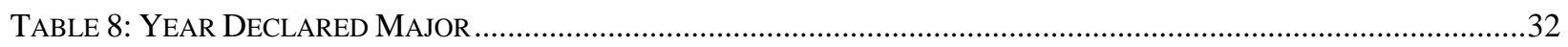

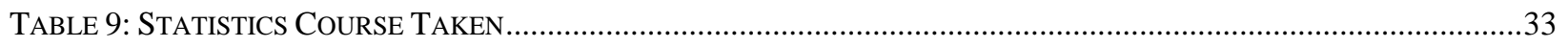

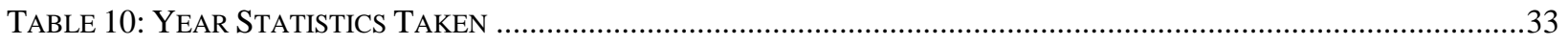

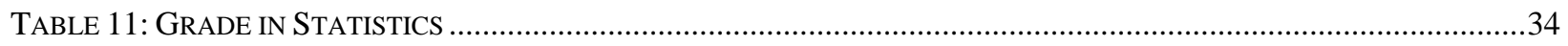

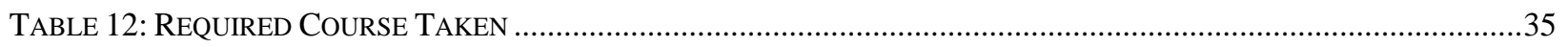

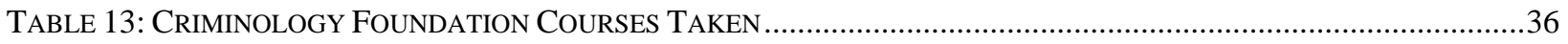

TABLE 14: SEQUENCING OF CAPSTONE ............................................................................................................37

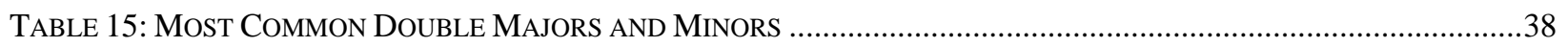

TABle 16: Percentage of Students TAking Special Courses with Average Credit Hours .............................39

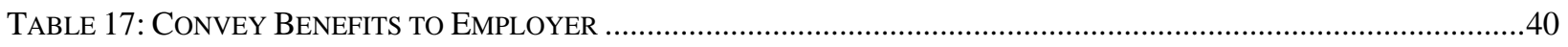

TABLE 18: DiSTINGUISH EMPIRICAL GENERALIZATIONS FROM STEREOTYPES ............................................................40

TABLE 19: FoRMULATE RESEARCH QUESTIONS/HyPOTHESES ..................................................................................41

TABLE 20: SEARCH FOR RESEARCH ARTICLES ON TOPIC OF INTEREST ….................................................................41

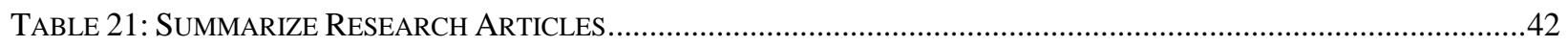

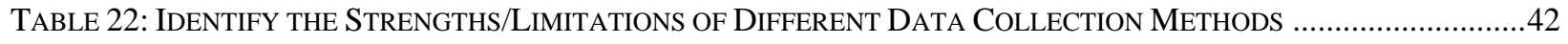

TABLE 23: IDENTIFY ETHICAL ISSUES IN SOCIAL RESEARCH ..................................................................................43

TABLE 24: WRITE A RESEARCH REPORT THAT IS UNDERSTANDABLE BY NON-SOCIOLOGIST/ANTHROPOLOGISTS .......43 


\section{List of Figures}

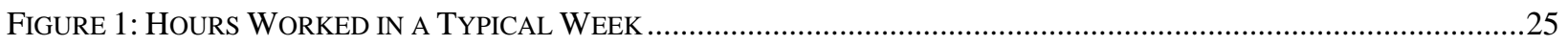

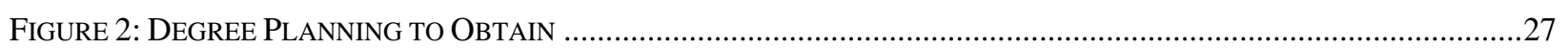

FigURE 3: NUMBER OF GRAdUATES BY MAJOR WITH SOCA AOES …..................................................................30

FIGURE 4: NUMBER OF GRADUATES FOR SOCA AND CRIM; 2004-2008................................................................30 


\section{Introduction}

Over the past twenty years, assessment has become an important process in higher education. The need for program assessment came into high demand in the late 80's it was becoming obvious that some students graduating from colleges were unable to read or write

effectively (Weiss, Crosbey, Habel, Hanson, and Larson 2001). It was clear that despite holding a degree, many students were not prepared to continue in their chosen careers. In 1988, the Secretary of Education ruled that all federally approved accreditation institutions must have some way of showing outcomes for the institution. Upon hearing that they needed to start showing outcomes, colleges across the United States started developing and enacting assessment programs (Palomba and Banta 1999, Banta 2001, Berheide 2001, O’Brien, Reidmann, Doraz, and Payne 2001). Outcomes assessment refers to "the measurement of student knowledge, skills, competencies, values, and perceptions (Eck, Johnson, and Wylie 2001: 10).

Other potential benefits of curriculum assessment have been identified. Eck et al. (2001:11) suggests that the primary reason for assessment "is ultimately to improve student learning and development by linking outcomes assessment with curriculum review and revision.” Howery (2001) from the American Sociological Association gives several reasons why it is important for departments to participate in assessment that are separate from mandated reasons. One of the core reasons is when assessment takes place within a department, it promotes better learning. This is because the first step to any good assessment is for the department to come up with a mission statement and learning objectives, which are the cornerstones to student learning. Another important reason is that assessment allows faculty to feel pride in the work they are doing and clearly see their overall contribution to the department and the entire institution. 
Despite potential benefits of assessment, getting colleges and the departments within them to do sound assessments has been difficult. According to Senter (2001), there are four reasons for this. First, many professors have gotten used to the idea of working independently to teach and conduct their research. However, with the introduction of assessment, they had to start answering not only to their department head, but also the university, their accrediting agency, or even sometimes the state. Second, many faculty see program assessment as just another thing that they have to do on top of their normal workload and teaching classes. Many faculty see assessment as something that gets in the way of their normal research. They see it as something that has to be done order to satisfy a higher official.

However, Senter (2001) argues that professors should use the opportunity to determine if they are meeting the needs of their students and whether they might be able to improve their program. The author sees assessment as a chance for the entire faculty to engage and exchange their ideas, rather than delegating it to a sole person in the department. Even though one person may be able to write up the final assessment report, the entire department needs to be involved in the assessment process from beginning to the end. The faculty should embrace assessment and think of it not as a burden, but as a chance to step back and take a look at their program.

The final two challenges to program assessment, according to Eck et al. (2001), are that some faculty may not have a clear understanding about student learning in college and may not take the idea of program assessment seriously. These go back to the other two reasons. When faculty are engaged in assessment it allows them to have an investment in their department. They are able to help form a mission statement and learning objectives which will allow them to get a better understanding of how their work in the classroom fits into the bigger picture (Weiss et al. 2001, Senter 2001, Eck et al. 2001, Howery 2001, Berheide 2001). 
The purpose of this thesis is to contribute to the curriculum assessment process in the Division of Sociology and Anthropology at West Virginia University. First, a literature review on assessment approaches and methods is presented. Next, the methodology for this project is described, including a review of the status of the Division's assessment process and the tools and analysis techniques being employed. Findings and implications are presented in two parts: Results of graduating senior surveys and transcript analyses (which offer insights on the larger curriculum), and recommendations for developing direct measures of student learning.

\section{Literature Review}

$\underline{\text { Assessment Approaches and Methods }}$

Curriculum assessment is a type of program evaluation. Program evaluation is important to conduct if an organization wants to see if a program or policy is being effective. There are two main purposes of evaluation research. Summative evaluation describes the overall quality or value of the program, while formative evaluation identifies strategies for improvement. Curriculum assessment utilizes both types of evaluation. The two main questions that a department should ask themselves while doing assessment are: what is the intrinsic value of our program and what is the value of this education for our students.

According to Wolfer (2007), program evaluation uses the system model, which is where the researcher is able to see that all parts of a program are linked together in some way. There are four parts of this model and each can be linked back to an academic program. First, there are inputs (grant money, program outline, etc.), which in terms of an academic program would be the mission statement and learning objectives. Then there is the activities/program process (what the program is going to do), which would be courses and advising in an academic program. Next, there is the results/output, which in an academic setting would be students earning their degree. 
Finally, outcomes would be the students' ability to successfully use what they learned within a department in real world settings. Wolfer (2007:434-435) states that the system model produces credible results, "because the model involves all aspects of the program from the initial program organization to the end results, and these components are tied together in a systematic way.” This is exactly the steps that a good assessment takes starting with the mission statement and ending with looking at the alumni. In both cases the information gathered goes back into the program to make improvements.

Once a department has decided that an assessment is necessary, they must determine the goals and method that will be used to carry out the assessment (Hohm 2001, American Association of Higher Learning 2001). Polomba and Banta (1999) along with others have outlined numerous steps that lead to a successful assessment of curriculum. Their first step, which is typically seen as the most important, is to agree on goals and objectives for learning. This step represents perhaps the most crucial step in program assessment because for a department to function properly, it must be clear on what it expects students to be able to accomplish once their education is complete. If the department does not have a clear understanding of their goals going into the assessment, then the rest of the assessment process will be worthless. Like any good research project, if the researcher does not have a clear understanding of what they are trying to research, then they will be unable to choose appropriate methods or interpret results effectively (Eck et al. 2001, Weiss et al. 2001, Polamba and Banta 1999, Hood et al. 2005, Hohm 2001, Palomba 2001, American Association for Higher Learning 2001).

Second, the department must design and implement a "thoughtful approach" to the assessment. This usually starts with an assessment of the curriculum. Curriculum assessment 
evaluates courses currently offered to ensure they meet the learning goals of the department and to ensure proper sequencing. This method focuses on whether the curriculum is designed in such a way to allow students to be successful. The third step is a student learning assessment, which evaluates how well learning outcomes are being met.

Multiple methods can be used during both assessment phases. Indirect methods include graduating senior and alumni surveys that allow students to reflect on their experiences within a program or class. Direct methods include techniques that require the students to actually show their skills and knowledge. This would include methods such as tests, papers, and classroom assignments.

Mixed methods are preferred because it would be very difficult to find one method that would help answer all the questions a department might need answered during an assessment. For example the use of surveys may be best for getting students' thoughts about the department and their experiences progressing through a particular program. Transcript analysis, portfolios, and the use of capstone courses will then be better measures to assess the actual learning. The key however is to choose assessment methods that are best suited for the department or program’s particular needs (Palomba and Banta 1999, Hood et al. 2001, Polomba 2001). Some common methods are described next.

Transcript analysis may be used by departments to better understand how their students are progressing with the course work involved in completing a program (Hood et al. 2001). According to Palomba and Banta (1999: 281), transcript analysis “allows for faculty to see patterns in course work and when it is combined with other assessment techniques . . . can help faculty examine and understand the patterns of courses that best enhance the learning and development of students.” For example, a department may want to know in what order a 
particular set of required courses was taken and if a particular order facilitates better learning. Some departments might also choose to use the students' grades as another way of assessing student learning. This will allow the department to see how their students are fairing in core courses. One of the reasons that transcript analysis can make an excellent assessment measure is that it is unobtrusive. Gaining access to these files, however, can sometimes be difficult depending on the type of policies the university or college might have in regard to who may have access to this information.

The use of surveys from the alumni is considered one of the better ways of determining the impacts of being part of a particular program (Hood et al. 2001). Alumni surveys are a way to get a glimpse at the experiences of students since graduation and what they think the department can improve on to make the experiences of future students better. The surveys also allow the department to see what happens to their students once they graduate. This includes employment, salaries, and if they feel they are truly using their degree to its fullest potential. This information will allow the department to determine what areas they need to improve upon in order to make their students more viable in the work force. If the students did not go straight into the work the force and decided to continue their education, the department can see what kind of programs the graduates moved into and how they are doing within those new programs.

One thing that must be kept in mind when asking questions about the graduates' current employment and how they are doing in their field is that this information can change several times in a five year period accordance with the economy. For example, if the economy is not doing well, more alumni may have postponed going into the work force and instead decided to continue their education and vice versa. An alumni survey usually asks questions regarding their experiences within the department itself. These types of questions allow the alumni to truly 
reflect on their educational experience, what they thought the department did well, and where they believe the department can make improvements. Information about the alumni's educational experiences can also be gathered through interviews with individuals or through the use of focus groups. When focus groups are used, "alumni are asked to concentrate their discussion on a few questions of significance to the department. Questions may be ... broad, asking alumni about the department's strengths and weaknesses. [Or, they] maybe be asked about specific aspects of their experiences ...” (Palomba and Banta 1999: 215).

Along with alumni surveys, some departments may decide to survey students within the department who are close to graduation. Graduating senior surveys, similar to alumni surveys, allow the department to learn about the experiences of their students during their time within the department. These surveys ask questions regarding courses, interactions with faculty and staff, career and future plans, and what the student did outside the program.

It is important during the assessment process, to consult with individuals that are on campus as well as those that are off campus. Alumni and employers can be just as useful as individuals that are involved with the department on a daily basis when it comes to learning information about the department. A data collection process that involves everyone (including students) should be designed and implemented. Students can be a useful source when it comes to data collection. Not only can they answer surveys and do assessment within course grading or “course imbedded assessment” (for example using capstone courses), robust assessment can be a good research opportunity for many students. The reason that assessment makes a good research project fir students is that a good assessment involves mixed methods, which allows students to participate in developing survey, analyzing survey, or even conducting interviews. Once the assessment is complete faculty should look back at the results, share them with everyone, and 
use them to the advantage of the department. Finally, the assessment process itself needs to be assessed. Did the process meet the goals of the department? Are there other methods that could have worked better? This will help the next time assessment takes place (Palomba and Banta 1999, Hohm 2001, Polomba 2001).

Methods for outcomes assessment are varied and include such methods as Major Field Tests, student portfolios, using the capstone experience, and pre and post testing. All of these methods have their advantages and disadvantages. The Major Field Test is a standardized test created by the Educational Testing Service (ETS) for a range of associate, undergraduate, and graduate programs. These are multiple choice tests that are typically given to students during their senior year. Some of the advantages to these tests are that the departments can see how their students compare to others on the national level. According to the ETS website (2009), faculty can add up to 50 questions of their own to the test in case there is certain special information on which they would like to assess their students. There are some disadvantages to this type of assessment as well. First, the undergraduate version of the test takes up to two hours to complete, making it somewhat time consuming. Another disadvantage is the cost of the test. The online tests cost \$24 each and the paper tests cost \$26 each (plus shipping and handling) making the test expensive for some departments.

The use of student portfolios is another way departments conduct an outcomes assessment. This usually consists of a collection of student work over the course of their time within a department, a class specifically dedicated to writing and the development of portfolios, or a random sample of student work from across the department. Some departments require their students to create a portfolio of their work over the course of their time within the department. This can be mandatory of all students or students can be chosen at random to participate in this 
type of assessment. Palomba and Banta (1999) suggest that when taking on portfolios as part of an assessment the faculty need to decide whether it will be graded or if it will be used purely for assessment. Either way, a rubric must be developed to assess the portfolios in both cases. A decision must also be made about what kind of items will be included in the portfolio and if the students will be required to do any additional work, like reflection papers on how they think they have improved over the course of the major. Cappell and Kamens (2002) argue that in order for this to be successful, requirements for all papers in the courses need to have clearly defined goals on how students will be graded.

Another way of using portfolios is to take random samples of papers from particular courses to see how students are doing in the department. According to Dorn (2001), these papers are usually taken over the course of a couple of years with about 30 papers per year. In this case the students need to be informed that their papers may be chosen (once chosen, the students will still need to give permission for their work to be used in the assessment process). Dorn (2001) recommends that a rubric be set up to evaluate the work and then grade the work on how it meets the learning objectives and use this information to determine how well the department is meeting its goals.

The final use of portfolios is either having an entire course dedicated to creating a portfolio or having a portfolio as a final project. According to Trepagnier (2004), when requiring students to develop a portfolio there needs to be clear expectations, usually in the form of rubrics. The use of portfolios also fosters self assessment to take place through reflection papers and the students knowing the papers are part of a larger end of course project. Jones (1999) used a portfolio project in a business course as a form of assessment and even though the students were involved in the discussion of how portfolios would be used, many of the students voiced 
frustration about the project mid semester in terms of how time consuming it seemed to be or not knowing what work to include. However, by the end many students found the portfolio as a way to practice the skills they had learned.

Some departments decide to use their capstone experiences as a way to assess their programs. Capstones are courses that require seniors to apply the skills they have learned in past courses. Berheide (2001) gives a few reasons why capstones are ideal for use in assessment. One, the paper that is developed makes the students demonstrate a higher understanding of sociological concepts. Two, the papers are usually in a standard research format. Third, the papers are a unique learning experience in research and presentation. Wagenaar (1993) warns that even though capstone courses can be used for assessment, consideration needs to be made that assessment does not define the capstone course in terms of how it is structured or graded. However, it can be used successfully to make sure the department is meeting its goals. Similar to other assessment methods, common rubrics are usually developed as a grading guideline for the papers.

The final method that is commonly used is pre and post testing of majors. This is usually done on a class basis. Students are given a test at the beginning of a course on terms or concepts that are covered in the class. They are then given the same test at the end of the course and the students' improvement is the means for assessment. These tests can be difficult to be given in higher level courses according to Palomba and Banta (1999). These authors claim that one of the major disadvantages at this level is the development of questions that "examine a higher order of thinking skills” (Palomba and Banta 1999: 153). 


\section{Methods}

Assessment in the Division of Sociology and Anthropology

In order to understand the goals of the assessment, one must look at the Division's mission statement, learning goals, and objectives that are set for students. In this case, the mission statement for the Division of Sociology and Anthropology has three basic tenants. First, students should gain a firm foundation in the scientific knowledge of structures, complexities, and dynamics of social groups, embedded in an appreciation for human diversity and social justice. Second, the division shall promote and foster the students' curiosity, critical and scientific thinking, and research abilities that are necessary to effectively explore social phenomena. Lastly, there should be a close collaboration among faculty and students across campus as they engage in scholarly research and build student success in the classroom.

The Division of Sociology and Anthropology offers two undergraduate majors. Students can graduate with degrees in Sociology and Anthropology (SOCA) or Criminology and Investigations (CRIM). Originally, the Division only had one major (Sociology and Anthropology) with three Areas of Emphasis (AOEs). These included anthropology, social inequality, and crime and social control. Due to the increasing interest of the crime and social control AOE and the growth of the Forensic Science Initiative at WVU, the Division created the Criminology and Investigations major in 2004. The Sociology and Anthropology major currently places greater emphasis on sociology coursework than on anthropology coursework, but the Division is building anthropology offerings. Although the Division temporarily suspended AOEs, students will be able to choose a sociology or anthropology AOE beginning in Fall 2009.

The Division of Sociology and Anthropology started its assessment process in Fall 2006. The faculty originally decided to work with the 12 learning objectives (that contained 42 
additional components) which were set forth by their governing body, the American Sociological Association (ASA). The 12 original objectives are listed below.

Students will:

1. Be able to describe the discipline of sociology and its role in contributing to our understanding of social reality.

2. Be able to describe the role of theory in sociology.

3. Be able to describe the role of evidence and qualitative and quantitative methods in sociology.

4. Be able to perform certain technical skills related to sociology.

5. Be able to describe the basic concepts in sociology and their fundamental theoretical interrelations.

6. Be able to identify how culture and social concepts operate

7. Be able to explain reciprocal relationships between individuals and society.

8. Be able to distinguish between macro/micro.

9. Know in depth two specialty areas within sociology

10. Be able to describe the internal diversity of American society and its place in the international context

11. Be able to think critically

12. Have the ability to develop sociological values.

The faculty then decided to break these 12 goals down into four preliminary areas according to their assessment report (2008). The areas and associated objectives are listed below. 
1. The practice and relevance of social research. Students should able to use the knowledge and skills they have acquired to make connections across society and distinguish between empirical generalizations and stereotypes.

2. Epistemologies and worldviews. Students should be able to identify the major sociological theoretical paradigms and the distinctions between them.

3. The structure and workings of a modern, global society. Students should be able to identify and describe the basic concepts and interconnections between them.

4. Critically appraise social events and information. Students should be able to use data and information and be able to assess the quality of that information to answer a research question.

The faculty also decided that these preliminary areas needed to be present in the skill sets that they expect every student to have upon graduation (i.e. writing, research, critical thinking, etc.).

In order to gain insights into their program, the Division distributed and collected alumni surveys in Fall 2006 and Spring 2007. There were 445 surveys that were mailed to all alumni that had graduated from the Division of Sociology and Anthropology between the years 2000 2005. A cover letter was attached to the surveys that informed the graduates that the survey was confidential and voluntary. Undergraduates from one of the capstone courses then handaddressed the envelopes and signed the cover letters. Undergrads were used to make the mailing stand out from other mail that the alumni may receive that they consider junk mail. A prepaid return envelope was provided to them as well. The first mailing containing all 445 graduates was sent out in October 2006. A second mailing was sent out in December 2006 in hopes of countering wrong addresses and poor response rate. Out of the 445 surveys that were distributed by mid January, 115 surveys were returned. This resulted in a 26\% response rate. 
An analysis of the alumni surveys indicates that the majority of the students had accepted full time work. Two of the biggest industries in which the alumni found employment were sales and the criminal justice system. Over one-quarter (27\%) of the alumni had gone on to graduate or professional school. The alumni were also asked about if they were satisfied with their experiences within the major and at WVU as a whole. The majority of the respondents said that they were satisfied with both. The alumni survey also contained open-ended questions. There were two main points that were brought up during these questions. First, the alumni said that the advising within the department needed to be improved. Second, the Division should help in job placement for the students (Division of Sociology and Anthropology 2008 Assessment Report).

Based on these surveys, steps were taken to improve advising within the department and career development as well. The first step that the Division took was to start the SOCA 199 course, “Orientation to Sociology and Anthropology,” in the Fall of 2007 as a way to get information out to pre-majors and address any questions that students may have about the interworkings of the Division. The next step that the Division took (came about in the Fall of 2008) was to start advising pre-majors within the department. The department advising included premajors with a class standing of sophomore or higher. In order to make this transition more manageable, the positions of five instructors were created to include advising responsibilities. The Division has also started to hold career events and they have invited alumni to speak about how they have utilized their degrees.

The Division initiated two additional steps in the curriculum assessment process. First it designed a graduating senior survey. Students in SOCA 311, Social Research Methods, helped design the instrument that was administered during the Spring of 2008 to students planning to 
graduate in May, August, or December. The graduating senior survey was intended to measure four things according to the Division’s assessment report.

- Experiences with the curriculum including courses, instructors, and advising

- Self assessment of their skilled-based learning outcomes

- Commitments to paid jobs, student organizations/teams, and volunteer work

- Future plans

Second, they developed a plan for using transcript analysis to learn the answers to the following seven questions about the majors.

1. What are the demographic characteristics of our majors?

2. How many and which pre-majors do students declare before they obtain major status in our Division?

3. When are they obtaining major status?

4. When are they taking statistics, and how many need to repeat to earn a C or higher?

5. When are they taking required courses in SOCA?

6. How many are completing double majors and minors, and in what fields?

7. How many are completing special courses, including professional field experiences, independent studies, and teaching practicums?

In addition, faculty have engaged in preliminary discussions of how to directly measure student outcomes. Two of the suggestions had to do with the pre and post tests and also how to utilize the capstone courses. 


\section{Graduating Senior Surveys}

Senior surveys were distributed in capstone and other 400-level courses near the end of the Spring 2008 term. Some of the instructors of these courses allowed for later return, while others had the students complete the surveys and turn them in during class. Participation in the survey was anonymous and voluntary. Sixty-six students completed the survey. The 2007 - 2008 school year had a total of 169 graduates, making this sample, 39\% of the graduates for the year. The distribution of majors in the sample however, is similar to the distribution of majors for the population (CRIM 75\% compared to 76\%; SOCA 25\% compared to 24\%).

The survey asked the respondents to answer questions regarding their experiences within the department. This included questions regarding their experiences within classes, advising, and a self assessment section that asked the respondents to rank their abilities when they entered college and how they think their abilities have improved after finishing their coursework. Along with asking questions regarding their experience within the department there were also questions that asked about their experiences outside of the department. This includes whether or not the respondent worked while in college, if they were in any clubs, internships, and volunteer work. Questions regarding future plans were asked in regards to job and further education. The respondent had to answer in what time frame they were considering applying to jobs or graduate programs and if they had taken any of the necessary steps.

\section{$\underline{\text { Transcript Analysis }}$}

Transcript analysis was used on the transcripts of 504 students that had graduated from the department between May 2004 through May 2008. Data were retrieved from the STAR system by a single faculty member. Once the data were collected, this faculty member blacked out all identifying information on the print outs. 
In order to determine at what point in time of their college career certain major events occurred (coming to WVU, entering the major, and when they were in other pre-majors), a two digit semester code was developed. The first part of the code signified their class standing (freshman (1), sophomore (2), junior (3), and senior (4)) and the second number signified what semester they were at the time. As an example, code " 23 ” would signify that the student was in their third semester of being a sophomore at that particular time. The codes were also used to determine when they took their major required courses as well as any teaching practicums, independent studies, and professional field experiences.

All analyses were run combining both majors, but differences between majors were also explored and identified. The transcript analysis also included information concerning the students' sex, residency status, major(s), minors, and their overall GPAs and within the major. Frequencies were run on these variables in order to determine the composition of the students within the department.

Special attention was given to the statistics course, because even though it is not taught within the department it is still a requirement for admission to the majors. It was also important to understand if the statistics requirement prevents students from getting accepted into the majors in a timely way. Grade distributions were run on the statistics courses to get a general idea of how students were doing in the course overall. Statistics were also run to find out how many students who took Understanding Statistics (STAT 111) had attempted Elementary Statistical Inference (STAT 211) first with a D or F. A frequency was also run on how many students had to repeat their statistics course to earn a $\mathrm{C}$ or higher.

Another concern when running this initial data was to see what sequence students were taking Social Research Methods (SOCA 311), Sociological Theory (SOCA 401), and their 
Capstone (SOCA 488). The reason that there is such concern over the course sequence of these particular classes is that the main goal of the capstone is that the student can take what they have learned in their core classes and be able to apply it successfully to a larger project. In order to be able to do this, the student would have had to successfully complete a methods course and theory, because these are two main areas that the student would be applying in the capstone. In order to determine the sequence that these classes were taken a new variable was created called CAPSEQ. The values that were used were 1: both 311 and 401 taken prior to 488, 2: only 311 prior to 488, 3: only 401 prior to 488, 4: neither taken before 488, or 88 for those students that did not have to take a capstone, because they entered WVU before Fall 2002 when it was not required.

The next variables that were identified were those that had to do with the year that the students' completed particular courses. These included all the core courses: Introduction to Sociology (SOCA 101), Introduction to Anthropology (SOCA 105), Social Research Methods, and Sociological Theory. The main idea behind running these variables was to see when in their college careers were they taking these courses, were they taking them early on or were they waiting to take them later. When it came to students who majored in CRIM, their foundation classes: Criminology (SOCA 223), Juvenile Delinquency (SOCA 233), and The Criminal Justice System (SOCA 330) were included in the analysis. Also if the student had chosen to take part in a teaching practicum, independent study, or professional field experience, data were collected on when they took it along with how many credits were taken.

\section{Direct Measures of Student Learning}

The final step involved looking at how other sociology departments complete their assessment. This part of the assessment process allows for recommendations to be made about 
how the Division of Sociology and Anthropology should continue with their assessment of learning outcomes. The sociology departments that were looked at were chosen at random after doing an internet search for assessment in sociology departments. The original goal was to find departments that were similar to the Division in terms of size and being joint departments. However, since there is not a requirement for departments to post their assessment information it made locating departments with similar characteristics as the Division impossible.

\section{Results: Curriculum Assessment}

\section{Graduating Senior Surveys}

Seventy-five percent of students majored in CRIM out of the remaining students, $13.8 \%$ majored in SOCA with a primary interest in sociology and 10.8\% majored in SOCA with a primary interest in anthropology.

\section{Experiences with the Program}

The admission process is the first step that students must go through in order to enter any of the majors offered under the Division of Sociology and Anthropology. The process is different for SOCA and CRIM majors. If the student is planning on majoring in Sociology and Anthropology they will automatically be transferred into the major once they have met the minimum requirements for admission. Any student interested in majoring in Criminology and Investigations must complete a formal application to the major in order to be accepted. This is done to manage the large student demand for the major. Once the student has been accepted into their chosen major there are another set of requirements that the student must meet in order to graduate with a degree. 
The graduating senior surveys contained four questions that had to do with requirements for admission and completing their chosen major (results are shown in Table 1). Ninety-four percent of CRIM majors compared to $81 \%$ of SOCA majors either strongly or somewhat agreed that requirements for admission were clear. This can be due to the fact that CRIM students have a more formal application process so they might be more aware of what it takes for them to get into the major than SOCA students. Next, 92\% of CRIM students compared to $88 \%$ of SOCA students strongly or somewhat agreed that requirements for completion were clear. Since this is only a slight difference, it could be explained by the students’ individual experiences with advising. In regards to the requirements for completion one student stated; "for the most part major requirements were clear, it got a little confusing when the requirements became more specific, i.e. intermediate, advanced, etc."

Table 1: Requirements for admission and completion of major

\begin{tabular}{|c|c|c|c|c|c|c|}
\hline & & $\begin{array}{c}\text { Strongly } \\
\text { Agree }\end{array}$ & $\begin{array}{c}\text { Somewhat } \\
\text { Agree }\end{array}$ & $\begin{array}{c}\text { Somewhat } \\
\text { Disagree }\end{array}$ & $\begin{array}{l}\text { Strongly } \\
\text { Disagree }\end{array}$ & Totals \\
\hline $\begin{array}{c}\text { Admission } \\
\text { Requirements }\end{array}$ & $\begin{array}{c}\text { CRIM } \\
(\mathrm{N}=49)\end{array}$ & $65.3 \%$ & $28.6 \%$ & $4.1 \%$ & $2.0 \%$ & $100 \%$ \\
\hline Clear & $\begin{array}{l}\text { SOCA } \\
(\mathrm{N}=17)\end{array}$ & $37.5 \%$ & $43.8 \%$ & $18.8 \%$ & --- & $100 \%$ \\
\hline Completion & CRIM & $49.0 \%$ & $42.9 \%$ & $8.2 \%$ & --- & $100 \%$ \\
\hline $\begin{array}{l}\text { Requirements } \\
\text { Clear }\end{array}$ & SOCA & $37.5 \%$ & $50.0 \%$ & $12.5 \%$ & --- & $100 \%$ \\
\hline Easy to Get into & CRIM & $26.5 \%$ & $34.7 \%$ & $20.4 \%$ & $18.4 \%$ & $100 \%$ \\
\hline $\begin{array}{l}\text { Courses for } \\
\text { Completion }\end{array}$ & SOCA & $43.8 \%$ & $37.5 \%$ & $12.5 \%$ & $6.2 \%$ & $100 \%$ \\
\hline $\begin{array}{c}\text { Easy to Find } \\
\text { Information on } \\
\text { Website }\end{array}$ & $\begin{array}{c}\text { BOTH } \\
(\mathrm{N}=66)\end{array}$ & $33.3 \%$ & $45.5 \%$ & $18.2 \%$ & $3.0 \%$ & $100 \%$ \\
\hline
\end{tabular}

The students were also asked about the ease of getting into courses that were required in order for them to graduate. The majority of students (65.1\%) either strongly agreed or somewhat 
agreed with this statement. Whereas, $19.7 \%$ of students somewhat disagreed and $15.2 \%$ of students strongly disagreed that it was not easy to get into required courses. One student wrote, "required courses had too few sections available each semester, causing them to fill up and become unavailable for students who truly need them." Another student stated, "I don't think it's fair that I have to compete w/ people who are taking SOCA classes as an elective to get classes I need."

The other question that was asked had to do with the ease of finding information on the SOCA website. Even though this question is not necessarily about requirements, the website could be one of the places that the students may go in order to find out requirement information or information about the Division as a whole. Forty-five percent of the students said that they somewhat agreed that it was easy and 33\% strongly agreed. However, there were $21.0 \%$ of students who either strongly or somewhat disagreed that it was easy.

One of the main interactions that students have with faculty within the department is through advising. At the time that this survey was administered, students were only advised within the department after they had been accepted to the major (typically during their junior year). If they were not officially in the major, they were assigned an advisor at the Undergraduate Academic Services Center (UASC) by the university. Results about experiences with advising can be found in Table 2 . When asked if they were satisfied with the quality of advising they had received outside of the Division, 33.8\% of the students strongly disagreed with the statement and $26 \%$ somewhat disagreed. There were $33.8 \%$ who somewhat agreed.

There were numerous statements in the two open-ended questions that would support these responses. One student stated, "The Undergraduate student advising center must have to be the most unorganized office at WVU. . Advisers were poorly trained and always unprepared for 
appointments. . ." Another student said, "The advising before my major was horrible and they scheduled me wrong and delayed me getting into the major because they said my previous stat grade was fine and it wasn't."

Seventy-five percent of the students either strongly agreed or somewhat agreed that they were satisfied with advising within the department. However, $24 \%$ of the students still responded that they somewhat or strongly disagreed that they were satisfied with advising within the department. A couple of students commented on their experience with group advising and the need for a more personal session. One such student said, "If each advisor would really take the time to sit down and actually go over each students records and any questions that one may have, I feel would really help out a good bit. It will also make us students feel more as a student rather than some number and [just] another face.” Over all $75.7 \%$ of the majors strongly or somewhat agreed that advising within the department was satisfactory compared to $40 \%$ of majors that thought the advising pre-department was satisfactory. This is probably due to the fact that the department is specifically focusing in on their majors, while the UASC deals with all majors.

Table 2: Satisfaction with Advising

\begin{tabular}{cccccc}
\hline $\mathrm{N}=66$ & $\begin{array}{c}\text { Strongly } \\
\text { Agree }\end{array}$ & $\begin{array}{c}\text { Somewhat } \\
\text { Agree }\end{array}$ & $\begin{array}{c}\text { Somewhat } \\
\text { Disagree }\end{array}$ & $\begin{array}{c}\text { Strongly } \\
\text { Disagree }\end{array}$ & Totals \\
\hline $\begin{array}{c}\text { Advising Pre- } \\
\text { Dept. }\end{array}$ & $6.2 \%$ & $33.8 \%$ & $26.2 \%$ & $33.8 \%$ & $100 \%$ \\
$\begin{array}{c}\text { satisfactory } \\
\text { Advising } \\
\text { within Dept. } \\
\text { satisfactory }\end{array}$ & $34.8 \%$ & $40.9 \%$ & $18.2 \%$ & $6.1 \%$ & $100 \%$ \\
\hline
\end{tabular}

Over half of the students (55.4\%) claimed they had attended all their advising meetings, $16.9 \%$ attended most, $23.1 \%$ attended some, and only $4.6 \%$ of the students said they did not attend any of their advising meetings. Crosstabs were then run using number of advising meetings attended and satisfaction with the advising received within the department. It was 
found that out of the 36 students that attended all of their meetings 36\% strongly agreed that they were satisfied with advising within the department. Of the students that attended most of their meetings $64 \%$ somewhat agreed compared to $18 \%$ that somewhat disagreed. For the students that only attended some of their meetings $53 \%$ strongly agreed compared to $7 \%$ of students that somewhat disagreed that they were satisfied with advising within the department. In other words, there was no clear relationship between number of sessions attended and satisfaction with advising.

The next set of questions had to do with the students' educational experience with quality of courses and instruction and how their grades correspond to their perceived learning and effort. The majority of students (92.4\%) strongly or somewhat agreed that the course content was of high quality (results shown in Table 3). Whereas, only $7.5 \%$ of the students that responded either somewhat disagreed or strongly disagreed that the course content was of high quality. Ninetyfour percent of students strongly or somewhat agreed that the instruction they received in their sociology courses were high quality. Very few (4.6\%) of the students that responded either somewhat or strongly disagreed that the instruction they received in their courses was high quality. The next question that the students were asked about had to do with the capstone and writing course that all students are required to take to get their degree. The capstone courses vary in their content depending on what topics interests them. The majority of the students (93.8\%) strongly or somewhat agreed that their capstone course helped them integrate the knowledge and skills from their major. Six percent either somewhat or strongly disagreed.

Eighty-six percent of students strongly or somewhat agreed that their grades did reflect what they learned. There were $13.6 \%$ of students somewhat disagreed or strongly disagreed that their grades reflected what they learned in their courses. The majority of the students (87.7\%) 
strongly or somewhat agreed that their grades reflected the effort that they put into their courses. However, 9.2\% of the students either somewhat or strongly disagreed that their grades reflected the effort that they put into their courses. Since the majority of students strongly or somewhat agreed with this set of questions it means that the Division is doing well in terms of the courses that are offered and how they are taught. It also shows that students feel that their grades not only reflect the amount of knowledge they have gotten out of the courses but also the effort they had to put into their courses to receive their grade.

Table 3: Sociology Courses

\begin{tabular}{cccccc}
\hline $\mathrm{N}=66$ & $\begin{array}{c}\text { Strongly } \\
\text { Agree }\end{array}$ & $\begin{array}{c}\text { Somewhat } \\
\text { Agree }\end{array}$ & $\begin{array}{c}\text { Somewhat } \\
\text { Disagree }\end{array}$ & $\begin{array}{c}\text { Strongly } \\
\text { Disagree }\end{array}$ & Totals \\
\hline $\begin{array}{c}\text { SOCA courses } \\
\text { high quality }\end{array}$ & $37.9 \%$ & $54.5 \%$ & $4.5 \%$ & $3.0 \%$ & $100 \%$ \\
$\begin{array}{c}\text { Instruction high } \\
\text { quality }\end{array}$ & $43.1 \%$ & $50.8 \%$ & $4.6 \%$ & $1.5 \%$ & $100 \%$ \\
$\begin{array}{c}\text { Writing/Capston } \\
\text { e helpful }\end{array}$ & $51.6 \%$ & $42.2 \%$ & $3.1 \%$ & $3.1 \%$ & $100 \%$ \\
$\begin{array}{c}\text { Grades reflect } \\
\text { learning }\end{array}$ & $33.3 \%$ & $53.0 \%$ & $10.6 \%$ & $3.0 \%$ & $100 \%$ \\
$\begin{array}{c}\text { Grades reflect } \\
\text { effort }\end{array}$ & $40.0 \%$ & $47.7 \%$ & $9.2 \%$ & $3.1 \%$ & $100 \%$ \\
\hline
\end{tabular}

\section{Extracurricular Activities}

Many students choose to participate in extracurricular activities that include clubs, intramural sports, university teams, jobs, and volunteer work. Also included in this section is information about internships. This information is important, because it gives insights on other commitments that may affect academic performance plus activities that may enhance their "marketability."

The students were asked if they had participated in an internship and if so they were asked to name the place of internship and to comment on their experience. There were $30.8 \%$ of students that participated in an internship. Of the students that said they participated in an 
internship, $45 \%$ of them were at a location that was within Monongalia County/Morgantown, WV. The most common local places that students completed their internships were the Monongalia County Sheriff's Department and the Monongalia County Probation Office. Other local places included Monongalia County Courthouse (no office specified), Monongalia County Teen Court, and the Morgantown Police Department. Another 40\% of the students participated in internships that were not local. These internships included police departments, Department of Justice, overseas internships, United States Secret Service, and special victims units. The remaining $15 \%$ of students did not specify the location of their internship.

The respondents were then asked if they worked while they were in school. Over half (55\%) said they had worked while they attended school. Of these respondents, most worked 1015 hours (40\%) or 20-29 hours in a typical week (43\%) (See Figure 1).

Figure 1: Hours Worked in a Typical Week

\section{Hours Worked}

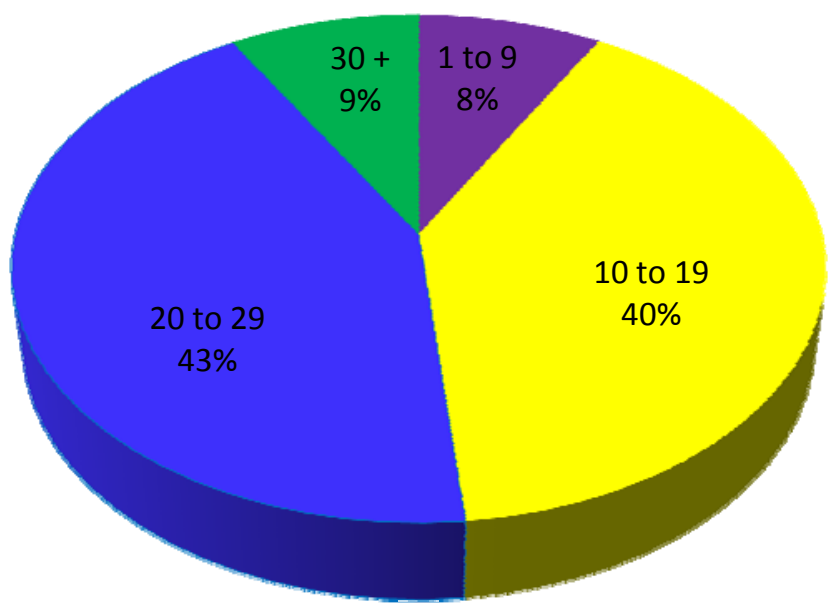

1 to 9

10 to 19

20 to 29

$30+$

The respondents were also asked about their participation in school organizations. There were

$47 \%$ of respondents that said they did participate in an organization, which included club sports, 
teams, and student organizations. Out of the respondents that did participate, $39 \%$ were a member of the Sociology, Anthropology and Criminology Association (SACA). There were 48\% of the respondents that participated in other clubs besides SACA. These clubs included Greek associations, honor societies, and language clubs, among others. Some of the respondents (26\%) participated in university teams including equestrian, boxing, wrestling and marching band to name a few. There were a small number of respondents (16\%) that participated in club sports as well. The respondents were also asked about their volunteer work. Thirty-six percent of respondents said they volunteered during school. The most common places that the respondents volunteered were at their church, Habitat for Humanity, Bartlett House, and the Boys and Girls Club.

\section{Future Plans}

Students were also asked about their future plans including highest degree they plan to obtain, graduate /professional school and further education, employment plans, and full time volunteer work. The first question the students were asked to respond to had to do with the highest degree the student planned to obtain. Thirty-three percent of students said that the highest degree that they were planning to obtain was a Bachelor's Degree, and 37.9\% of students that were planning on obtaining a Master's Degree (Figure 2). An additional 17\% of students that said they were going to obtain either a Doctoral or Professional Degree and $12.1 \%$ of students were undecided. There were some distinct differences once this question was broken down by major. Fifty percent of students majoring in SOCA said they would go on to receive a Master's compared to 35\% of students majoring in CRIM. Also SOCA students were more likely to go on to receive a Doctoral degree (25\% compared to 2\% of CRIM majors). CRIM majors were more likely to want to receive a Professional degree (12\% compared to zero SOCA students). This 
shows that while many students are planning on obtaining either a Bachelor's or Masters degree in both majors when it comes down to a Doctoral and Professional degree there is a definite difference. This shows that the students in the majors are on different paths. The CRIM students most likely are pursuing a law degree to work in the private sector where the sociology students are looking more towards academia.

Figure 2: Degree Planning to Obtain

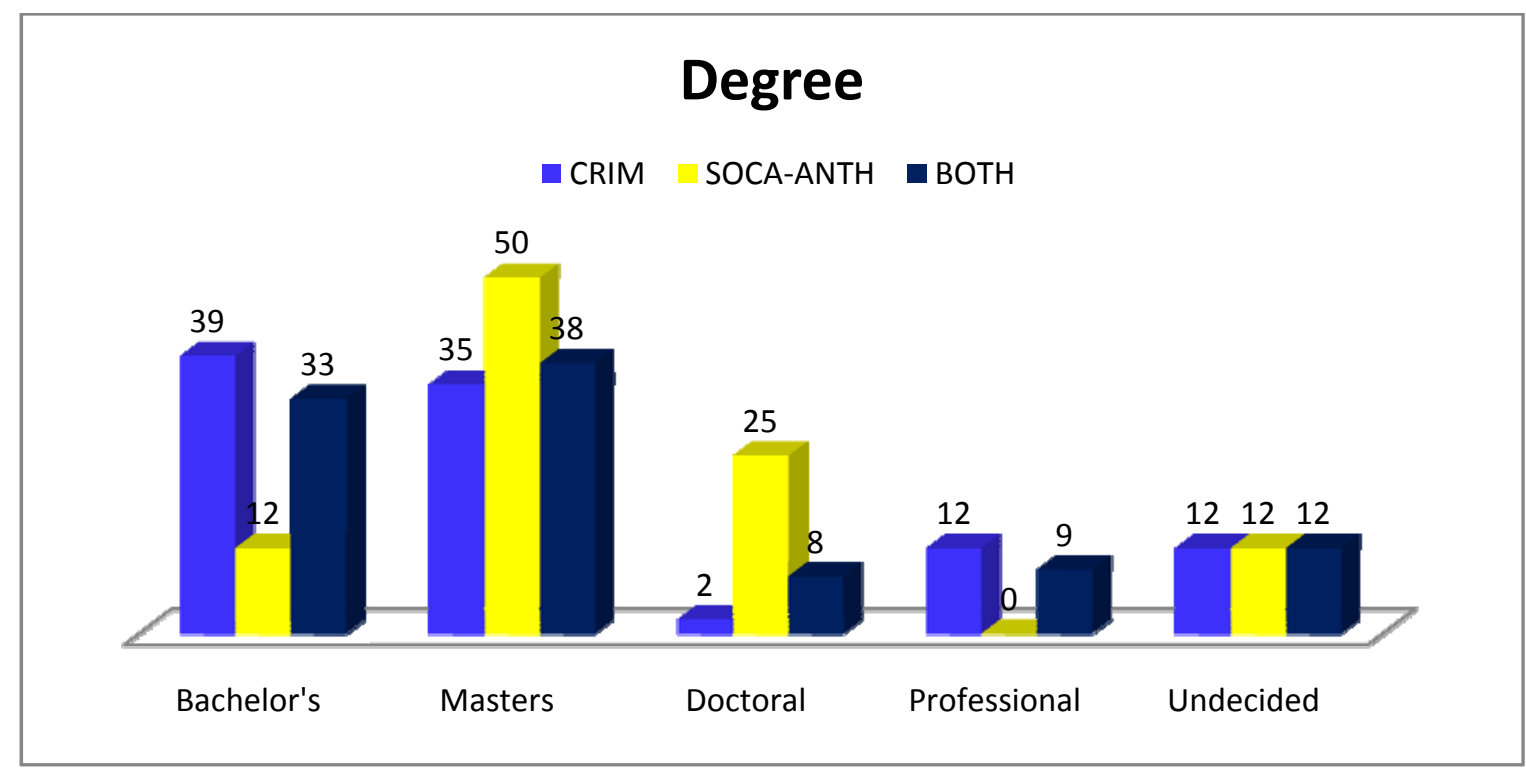

Respondents were asked questions regarding the application process to graduate and professional school. The first question asked students if they planned to apply to graduate school within one year of graduation. Over half (60.6\%) of students claimed that they would be applying to graduate school within one year of graduation. Of the $39.4 \%$ of students that said they would not apply within a year, 58.8\% said they planned to apply to graduate school within five years of graduation. Of the students that responded that they would be applying to graduate school within a year of graduation, 34.6\% had already applied and 50\% of those that applied had been accepted. These students were accepted to Archeology, Criminal Justice, and Sociology programs in West Virginia, Maryland, Nebraska, and Ohio. 
The students were also asked about their plans for searching for a job. Students were asked if they plan to seek a job within the first year of graduating. There were $70.8 \%$ of students that stated that they planned to find a job within a year. Out of the $29.2 \%$ of students that said they would not be searching for a job, $87.5 \%$ said they would within five years of graduating. Of the students that said they would be applying within a year a majority (91.1\%) said they had not accepted a job. The $8.9 \%$ of students that had accepted jobs as a law clerk, bank teller, and one did not mention position. These positions were located in Alabama, Delaware, and Ohio.

The respondents were also asked if they were going to pursue any type of extra training besides graduate or professional school. Forty percent of the respondents that said they were thinking about pursuing further training. The most common form of additional training was attending a police academy (42\%). An additional $15 \%$ did not specify the type of extra training they may be pursuing. Sixty-four percent said they would not consider working in a job that was unrelated to the major. Respondents were also asked if they were considering full time volunteer work. An overwhelming 94\% of the respondents said they were not. Out of the few respondents that were considering volunteer work as an option, they were thinking of working at an art foundation, volunteer fire fighter, and for Casa for Kids.

The respondents were asked about how many faculty members that they felt they knew well enough to be comfortable asking them for a recommendation. The most common response was three faculty members at $34 \%$. In addition, $23 \%$ said there was at least one and $21 \%$ said there were at least two faculty members they would ask for a recommendation. There were $13 \%$ of respondents that said they knew four or more faculty members well enough to ask for a recommendation. 


\section{$\underline{\text { Transcript Analysis }}$}

When frequencies were run on the sex and residency status of the students differences were found between majors, especially when it came to residency status (results shown in Table 4). Students majoring in CRIM were more likely than SOCA majors to be female (56.6\% compared to 51.2\%) and particularly to be non-residents (64.8\% compared to $46.2 \%)$. Overall, $54 \%$ of students were female and $46 \%$ male. Fifty-five percent were non-residents and $45 \%$ residents. This shows that the Division is capable of bringing in and retaining bright, out of state students, which is important because the more out of state students the Division brings in the more money it brings in for the university as a whole. The composition of majors has changed over the years. As seen in Figures 3 and 4 the number of graduates in CRIM has climbed drastically since its inception and the number of students majoring in SOCA has declined. This is most likely the result of students being more interested in the CRIM major based on the emphasis that the University has placed on forensics, which potentially has drawn more students to the school.

Table 4: Composition of Students

\begin{tabular}{cccccc}
\hline Major & \multicolumn{2}{c}{ Sex } & \multicolumn{2}{c}{ Residency } & \\
& Male & Female & Resident & $\begin{array}{c}\text { Non- } \\
\text { Resident }\end{array}$ & Totals(n) \\
\hline SOCA & $48.8 \%$ & $51.2 \%$ & $53.5 \%$ & $46.2 \%$ & 260 \\
CRIM & $43.4 \%$ & $56.6 \%$ & $35.2 \%$ & $64.8 \%$ & 244 \\
BOTH & $46.2 \%$ & $53.8 \%$ & $44.6 \%$ & $55.2 \%$ & 504 \\
\hline
\end{tabular}


Figure 3: Number of Graduates by Major with SOCA AOEs

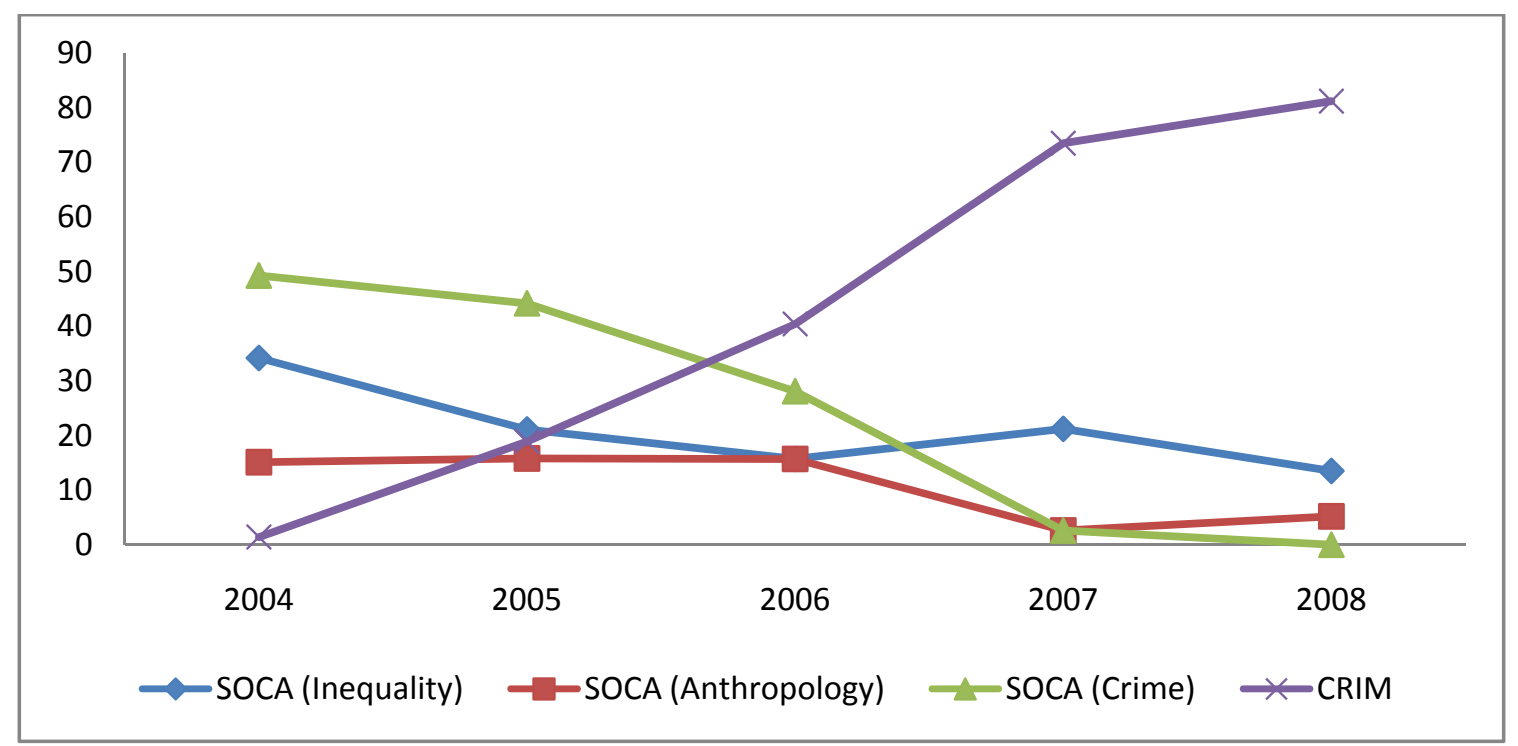

Figure 4: Number of Graduates for SOCA and CRIM; 2004-2008

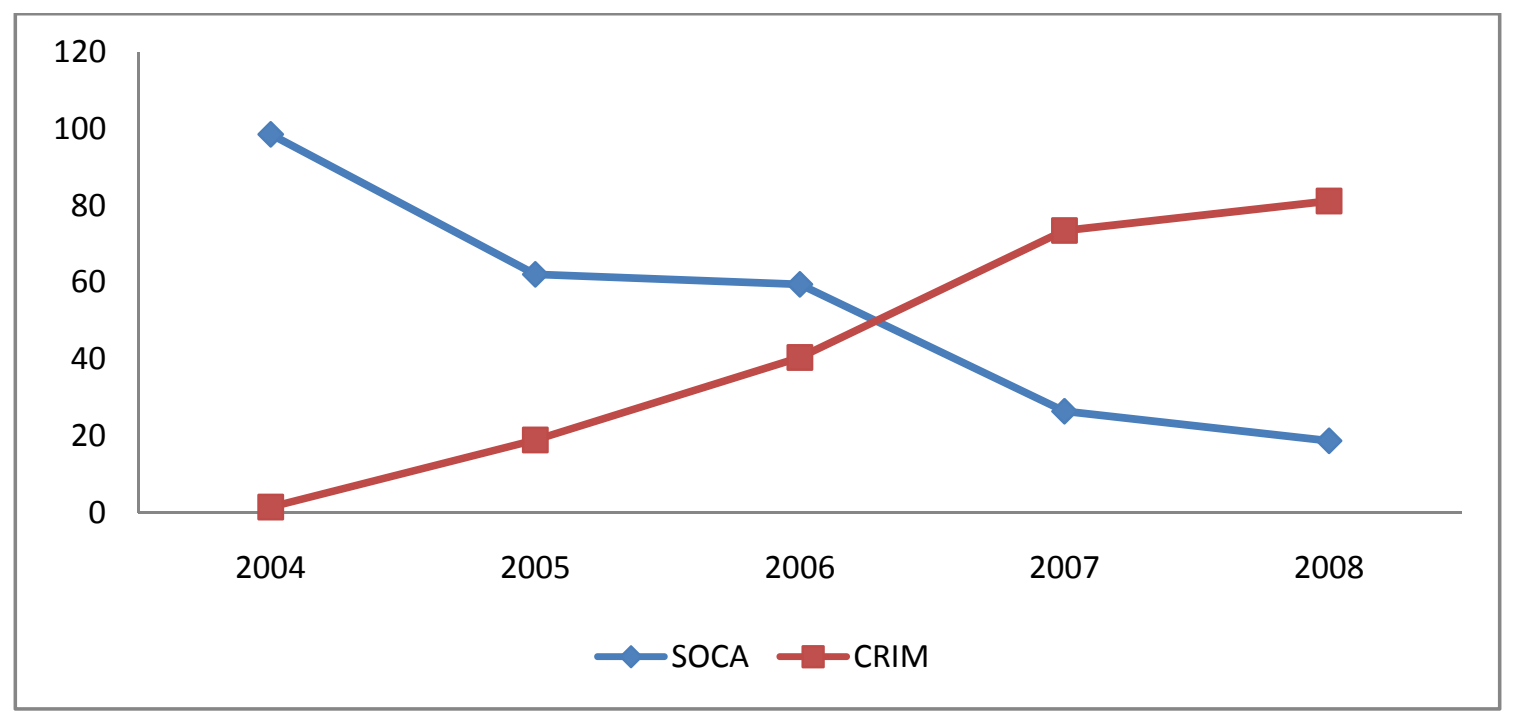

In order to get an overview of the data at hand and also to really differentiate between students that majored in SOCA and those that majored in CRIM, numerous univariate statistics were run on the data. In summarizing the two majors it was found that they are very similar when it came to the percent that double majored and percent that choose to pursue a minor. However, CRIM majors preformed slightly better than SOCA majors in relation to overall GPA (3.06 compared to 2.89) and SOCA GPA (3.26 compared to 3.04). 
Table 5: Academic Information by Major

\begin{tabular}{ccccccc}
\hline & $\begin{array}{c}\text { \# in } \\
\text { Major }\end{array}$ & $\begin{array}{c}\text { Average } \\
\text { \# of Pre- } \\
\text { Majors }\end{array}$ & $\begin{array}{c}\% \\
\text { Double } \\
\text { Major }\end{array}$ & $\begin{array}{c}\% \\
\text { Minor }\end{array}$ & $\begin{array}{c}\text { WVU } \\
\text { GPA }\end{array}$ & $\begin{array}{c}\text { SOCA } \\
\text { GPA }\end{array}$ \\
\hline SOCA & 260 & 1.78 & $8.8 \%$ & $30.4 \%$ & 2.89 & 3.04 \\
CRIM & 244 & 1.55 & $8.2 \%$ & $34.0 \%$ & 3.06 & 3.26 \\
BOTH & 504 & 1.67 & $8.5 \%$ & $32.1 \%$ & 2.97 & 3.44 \\
\hline
\end{tabular}

Table 6 shows information about pre-majors. The average number of pre-majors for all the students was 1.67. There is not much difference between the individual majors with SOCA being 1.78 and CRIM being 1.55. Table 7 shows a breakdown of number of pre-majors declared by major. The top three pre-majors for students who had declared another major before declaring SOCA were: General Studies (40.0\%), Business and Economics (20.0\%), and Psychology (10.4\%). The most common pre-majors for students that eventually declared CRIM were Forensics (42.6\%), General Studies (30.3\%), and Political Science (8.6\%). CRIM students may have been drawn originally to the university, because of the emphasis that the school places on their Forensics program. This just shows that both majors have different interests and are able to explore their interests within multiple courses offered in the Division.

Table 6: Most Common Pre-Majors

\begin{tabular}{ccc}
\hline Top Three & SOCA & CRIM \\
& N =222 & N = 220 \\
\hline ONE & General & FIDP \\
& $40.0 \%$ & $42.6 \%$ \\
TWO & B\&E & General \\
& $20.0 \%$ & $30.3 \%$ \\
THREE & PSYC & POLS \\
& $10.4 \%$ & $8.6 \%$ \\
\hline
\end{tabular}


Table 7: Number of Pre-Majors Declared

\begin{tabular}{ccc}
\hline $\begin{array}{c}\text { Number } \\
\text { Declared }\end{array}$ & SOCA & CRIM \\
$\mathrm{N}=260$ & $\mathrm{~N}=244$ \\
\hline 0 & $13.5 \%$ & $9.8 \%$ \\
1 & $46.2 \%$ & $43.0 \%$ \\
2 & $27.7 \%$ & $32.4 \%$ \\
3 & $10.8 \%$ & $12.7 \%$ \\
4 & $1.2 \%$ & $1.2 \%$ \\
5 & $0.4 \%$ & $0.8 \%$ \\
\hline
\end{tabular}

The Division is very interested in exactly when students are declaring their major. Ideally students should be declaring their major within their junior year, preferably the first semester. Results for year majors are declared can be found in Table 8. Students that are majoring in SOCA are split between their junior (45.7\%) and their senior (48.1\%) years. However, 55.7\% of CRIM majors are declaring their major within their senior year with 35.6\% declaring during their junior year. The Division should be concerned that a large portion of their students are declaring during their senior year. They need to determine why students are waiting to declare their major so late in their college career. I theorize that this may be linked to when they are completing their requirements for admission to the major particularly the statistics requirement.

Table 8: Year Declared Major

\begin{tabular}{ccc}
\hline Year Declared & SOCA (N=260) & CRIM (N=244) \\
\hline Sophomore & $0.8 \%$ & --- \\
Junior & $45.7 \%$ & $35.6 \%$ \\
Senior & $48.1 \%$ & $55.7 \%$ \\
Unknown & $5.4 \%$ & $8.6 \%$ \\
(double majors) & & \\
\hline
\end{tabular}

When frequencies were run on the statistics requirement of both majors it was looked at for everyone in both majors and then was looked at separately by major. The STAT course that is required of students differs by major. SOCA students are advised to take STAT 211 or higher, 
but can take STAT 111. CRIM students are required to take 211 or higher to fulfill their requirement. Results for the statistic courses taken and the year they were taken can be found in Tables 9 and 10. Forty-seven percent of SOCA students take 111, while $38.1 \%$ choose to take 211 instead. Students majoring in SOCA most commonly complete their STAT requirement during their junior (38.4\%) and senior (31.5\%) years. An overwhelming 93.4\% of CRIM students complete STATs 211 with 6.2\% either taking STAT 215 or ECON 225. The majority of CRIM students complete their STAT requirement during their sophomore (37.7\%) and junior (38.5\%) years. CRIM students may be completing their STAT requirement slightly earlier than SOCA students because that they have to have completed it in order to apply to the major. However, this could also be the reason students are not declaring their major late as well.

Table 9: Statistics Course Taken

\begin{tabular}{ccc}
\hline $\begin{array}{c}\text { STAT } \\
\text { Course }\end{array}$ & $\begin{array}{c}\text { SOCA } \\
(\mathrm{N}=260)\end{array}$ & $\begin{array}{c}\text { CRIM } \\
(\mathrm{N}=244)\end{array}$ \\
\hline 111 & $47.7 \%$ & ---- \\
211 & $38.1 \%$ & $93.4 \%$ \\
215 & ---- & $3.3 \%$ \\
ECON 225 & $13.8 \%$ & $2.9 \%$ \\
Transfer & $0.4 \%$ & $0.4 \%$ \\
\hline
\end{tabular}

Table 10: Year Statistics Taken

\begin{tabular}{ccc}
\hline $\begin{array}{c}\text { Year } \\
\text { STAT }\end{array}$ & $\begin{array}{c}\text { SOCA } \\
(\mathrm{N}=260)\end{array}$ & $\begin{array}{c}\text { CRIM } \\
(\mathrm{N}=244)\end{array}$ \\
\hline Freshman & $3.5 \%$ & $4.0 \%$ \\
Sophomor & $19.6 \%$ & $37.7 \%$ \\
e & & \\
Junior & $38.4 \%$ & $38.5 \%$ \\
Senior & $31.5 \%$ & $15.5 \%$ \\
Prior to & $7.3 \%$ & $4.1 \%$ \\
WVU & & \\
TOTAL & $100 \%$ & $100 \%$ \\
\hline
\end{tabular}

The grade distribution of the students' final grades in STAT was very similar between the two majors. Results are shown in Table 11. Around forty percent for both SOCA (41.5\%) and 
CRIM (40.2\%) received a C. Twenty-nine percent of students in both majors received a B and $14.2 \%$ of SOCA and $19.3 \%$ of CRIM students received an A. Ten percent of SOCA students received a $\mathrm{D}^{1}$ compared to only $1.2 \%$ of CRIM students. $\mathrm{C}$ is the minimum grade that students must receive to meet major admission requirements in STATs currently within the Division. The Division should be slightly concerned that good subsets of their students in both majors are only receiving the minimum required grade.

Table 11: Grade in Statistics

\begin{tabular}{ccc}
\hline GRADE & $\begin{array}{c}\text { SOCA } \\
(\mathrm{N}=260)\end{array}$ & $\begin{array}{c}\text { CRIM } \\
(\mathrm{N}=244)\end{array}$ \\
\hline $\mathrm{A}$ & $14.2 \%$ & $19.3 \%$ \\
$\mathrm{~B}$ & $29.2 \%$ & $29.9 \%$ \\
$\mathrm{C}$ & $41.5 \%$ & $40.2 \%$ \\
$\mathrm{D}$ & $10.0 \%$ & $1.2 \%$ \\
Grade & $9.4 \%$ & $5.0 \%$ \\
unavailable & & \\
(transfer) & & \\
\hline
\end{tabular}

The department wanted to know of the students that had taken 111, how many had attempted 211 without success. It was found that $4 \%$ of the students had taken 211 first without success and $96 \%$ had not attempted 211 , before taking trying to take 111 . Also when it came to retaking any statistics course because of unsuccessful completion (D or F), it was found that $88.1 \%$ of students did not have to repeat statistics whereas $11.9 \%$ did. These results only include students that D/F repeated a class. Since the data do not include those students that withdrew from their statistics class for whatever reason these results need to be considered a conservative estimate. Withdraws were not treated as attempts, because there was no way to tell why they withdrew from the class. It could have been that they were failing the class, but it could also be

\footnotetext{
${ }^{1}$ A grade of D used to be accepted for the SOCA major and some 2004 graduates had been accepted under that standard.
} 
because of a personal problem. There is just no way of determining why the student withdrew from the course based on the transcripts.

When students take their major requirement classes is important, because certain classes are best taken earlier and others later during their college career. An example of this would be that SOCA 101 Introduction to Sociology is best taken during the first two years, because it is considered an introductory course. The frequencies for year taken for SOCA 101 and 105 found that $68.4 \%$ of students have taken SOCA 101 within their first two years of college. Also 66.7\% have also taken SOCA 105 within the first two years. The majority of students (97.4\%) took SOCA 311 during their junior or senior year in college. Almost all of the students (99.2\%) took SOCA 401 during their junior or senior year. Results can be found in Table 12.

Table 12: Required Course Taken

\begin{tabular}{ccccc}
\hline YEAR & 101 & 105 & 311 & 401 \\
\hline Freshman & $36.7 \%$ & $27.4 \%$ & --- & --- \\
Sophomore & $31.7 \%$ & $39.3 \%$ & $1.4 \%$ & $.6 \%$ \\
Junior & $11.4 \%$ & $21.8 \%$ & $52 \%$ & $16.3 \%$ \\
Senior & $2.6 \%$ & $7.5 \%$ & $45.6 \%$ & $82.9 \%$ \\
Before WVU & $17.7 \%$ & $4 \%$ & $.2 \%$ & $.2 \%$ \\
Not Available & --- & --- & $.8 \%$ & --- \\
\hline
\end{tabular}

The next frequencies had to do specifically with those students that majored in Criminology. These students are required to take two of the three foundation classes (SOCA 232, 233, and 330). Results can be found in Table 13. Most of the students that took 232 and 233 courses took them within their sophomore or junior year ( $75 \%$ for each course). However, when it came to SOCA 330 it was found that $57.4 \%$ of CRIM majors did not take this course. Of the Criminology students that did take this course, 36.9\% took it during their sophomore or junior year. The lower amount of students that chose to take SOCA 330 could be because it is a 300 
level course where the other two courses are 200 level, which may cause students not to take it because they think it would be harder class.

Table 13: Criminology Foundation Courses Taken

\begin{tabular}{cccc}
\hline YEAR & $\begin{array}{c}232 \\
(\mathrm{~N}=224)\end{array}$ & $\begin{array}{c}233 \\
(\mathrm{~N}=222)\end{array}$ & $\begin{array}{c}330 \\
(\mathrm{~N}=104)\end{array}$ \\
\hline Freshman & $1.2 \%$ & $1.6 \%$ & --- \\
Sophomore & $30.7 \%$ & $23.4 \%$ & $4.5 \%$ \\
Junior & $44.3 \%$ & $52 \%$ & $14.8 \%$ \\
Senior & $11.1 \%$ & $11.1 \%$ & $22.1 \%$ \\
Before WVU & $4.5 \%$ & $2.9 \%$ & $1.2 \%$ \\
Never Taken & $8.2 \%$ & $9 \%$ & $57.4 \%$ \\
\hline
\end{tabular}

When looking at the sequencing of the capstone (SOCA 488), for students that were required to take a capstone, in regards to Social Research Methods (SOCA 311) and Theory (SOCA 401) it was found that $49.5 \%$ of SOCA and over half (51.1\%) of CRIM students take both 311 and 401 before they take their capstone. However, about 38\% of students that major in SOCA (37.8\%) and CRIM (38.9\%) only take 311 before they take their capstone while only 4.5\% of SOCA students and 1.3\% CRIM only took 401 before the capstone. Also around 9\% of both majors take neither before 311 or 401 before their capstone. There are also 32.5\% of all students that did not need to take a capstone in order to earn their degree, because they entered the university before Fall of 2002. Results are shown in Table 14. The Division should be pleased that at least half of students in both majors are taking 311 and 401 before taking they are taking their capstone course. This means that they are going into this encompassing course well prepared. They should also not be concerned that a good portion of their students are only taking 311, because even though they are not taking 401 they are still going into the capstone with a basic understanding of research methods. 
Table 14: Sequencing of Capstone

\begin{tabular}{ccc}
\hline Capstone Sequence & $\begin{array}{c}\text { SOCA } \\
(\mathrm{N}=260)\end{array}$ & $\begin{array}{c}\text { CRIM } \\
(\mathrm{N}=244)\end{array}$ \\
\hline Both taken before 488 & $49.5 \%$ & $51.1 \%$ \\
Only 311 Taken before 488 & $37.8 \%$ & $38.9 \%$ \\
Only 401 Taken before 488 & $4.5 \%$ & $1.3 \%$ \\
Neither Taken before 488 & $8.1 \%$ & $8.7 \%$ \\
Total & $100 \%$ & $100 \%$ \\
\hline
\end{tabular}

Thirty percent of SOCA students and 34\% of CRIM students have declared at least one minor. Results are shown in Table 15. Among students with minors, forty-nine percent of both majors chose Communications Studies (COMM) as their minor. The second most common minor chosen by SOCA majors is Business Administration (10.1\%), whereas the second minor chosen by CRIM students is Spanish (14.5\%). Five percent of SOCA students chose either Spanish or History. However, 7.2\% of CRIM students chose Business Administration as the third most common minor. It is surprising that students in both majors chose Business Administration, because it is one of the most difficult minors at the university and requires 21 credit hours. However, this goes back to students especially SOCA students having a pre-major of Business and Economics and could be a way that the students satisfy both their interest in Sociology and Business. It is also not surprising that CRIM majors choose Spanish as a pre-major because people who are bilingual in Spanish are in high demand especially in the criminal justice sector.

About eight percent of both majors, 8.8\% SOCA and 8.2\% CRIM, have pursued an additional major. The most common double major for SOCA students is History (30.4\%), whereas it is Psychology (40\%) for CRIM majors. The second most common double major is Philosophy (13\%) for SOCA and Sociology (20\%) for CRIM majors. Criminology students are usually discouraged by faculty to choose SOCA as a double major, because similar material is covered in both types of courses. About nine percent (8.7\%) of SOCA students choose Political 
Science or Women's Studies as a double major and 15\% of CRIM students choose Political

Science. This shows that SOCA students choose more abstract majors, whereas CRIM majors tend to choose majors that can easily be applied within the criminal justice field.

Table 15: Most Common Double Majors and Minors

\begin{tabular}{ccccc}
\hline \multirow{2}{*}{ Top Three } & \multicolumn{2}{c}{ SOCA } & \multicolumn{2}{c}{ CRIM } \\
ONE & COMOrs $(\mathrm{N}=79)$ & Doubles(N=23) & Minors(N=83) & Doubles(N=20) \\
& $49.4 \%$ & HIST & COMM & PSYC \\
TWO & BUSADMN & $30.4 \%$ & $49.4 \%$ & $40.0 \%$ \\
& $10.1 \%$ & PHIL & SPAN & SOCA \\
THREE & SPAN/HIST & POLS/WMST & BUSADMN & BO.0\% \\
& $5.1 \%$ & $8.7 \%$ & $7.2 \%$ & $15.0 \%$ \\
\hline
\end{tabular}

Students have the option of taking a Teaching Practicum (490), Professional Field Experiences (491), and Independent Studies (495) during their college career. Almost nine percent (8.5\%) of SOCA and $10.7 \%$ of CRIM students took a Teaching practicum with average credit hours of three for both majors (Table 16). Thirty percent of CRIM majors and $12.7 \%$ of SOCA majors participated in a Professional Field Experience and on average taking three credit hours. Finally, 9.6\% of SOCA students and 18.9\% of CRM majors took an Independent Study with once again three credit hours being the average. The most important finding from this set of data is that there are more CRIM students that participate in Professional Field Experience (or internship) then SOCA students. This might be because CRIM students are drawn to corrections and law based jobs and SOCA students might not know how to find places to intern since sociology training can be applied to many different areas. The Division might want to look into helping the SOCA find internship opportunities for these students to improve this number. 
Table 16: Percentage of Students Taking Special Courses

\begin{tabular}{ccccc}
\hline COURSE & SOCA & Credit & CRIM & Credit \\
& $(\mathrm{N}=260)$ & Hrs. & $(\mathrm{N}=244)$ & Hrs. \\
\hline Teaching Practicum (490) & $8.5 \%$ & 3 & $10.7 \%$ & 3 \\
Prof. Field Experience (491) & $12.7 \%$ & 3 & $29.9 \%$ & 3 \\
Independent Study (495) & $9.6 \%$ & 3 & $18.9 \%$ & 3 \\
\hline
\end{tabular}

Summary

Based on the Graduating Senior Surveys and the Transcript Analysis there are definitely places that the department needs to look into improving. First, they need to work on making the group advising more personal so students do not just feel like they are number. Second, improvements need to be made with internships and career placement. In terms of the transcript analysis the key findings are as follows. First, they need to work on the statistics requirement. The most likely solution would be to bring statistics into the department, which would cause students to do better in the course and most likely take it earlier. If this is done it will most likely have an effect on when students declare their major. Second, they should think about reworking the numbering for their methods, theory, and capstone to try to get students to take the course in a more logical order. These are the main areas that the department should focus.

\section{Results: Student Outcomes Assessment}

The first indirect outcome assessment was part of the graduating senior surveys; students were asked to assess themselves on how they perceived their level prior to WVU and then again at the end. They had to answer a series of questions that dealt with skills and had to rank themselves on where they thought they were with those skills before coming to college and where they believe those skills to be now since they will be graduating soon. 
Crosstabs (results are shown in Appendix A) were run for each of the skills based on questions where the students self assessed prior to West Virginia University and then again at the end of their academic career. Over half of the students (57\%) claimed that they had a low ability to explain the benefits of sociological training to potential employers prior to WVU and out of these students $46 \%$ claimed they improved to a high level. The most common improvements were by two (37\%) and three (26.2\%) skill points (Table 18).

Table 17: Convey Benefits to Employer

\begin{tabular}{|c|c|c|c|c|c|c|c|}
\hline \multicolumn{4}{|c|}{ Started WVU } & \multicolumn{4}{|c|}{ Now } \\
\hline 1 (low) & 2 & 3 & 4 (high) & 1 (low) & 2 & 3 & 4 (low) \\
\hline $56.9 \%$ & $33.8 \%$ & $7.7 \%$ & $1.5 \%$ & $3.1 \%$ & $9.2 \%$ & $41.5 \%$ & $46.2 \%$ \\
\hline \multicolumn{4}{|c|}{ Change } & & & & \\
\hline None & +1 & +2 & +3 & & & & \\
\hline $9.2 \%$ & $27.7 \%$ & $36.9 \%$ & $26.2 \%$ & & & & \\
\hline
\end{tabular}

At the start of their career at WVU, over half (53\%) rated themselves a two for the ability to distinguish between empirical generalizations and stereotypes, with $25 \%$ giving themselves a three. The majority (80\%) gave themselves a ranking of a four by the end of their career. The most common increase was by 2 points (55\%). Results shown in Table 18.

Table 18: Distinguish Empirical Generalizations from Stereotypes

\begin{tabular}{|c|c|c|c|c|c|c|c|}
\hline \multicolumn{4}{|c|}{ Started WVU } & \multicolumn{4}{|c|}{ Now } \\
\hline 1 (low) & 2 & 3 & 4 (high) & 1 (low) & 2 & 3 & 4 (low) \\
\hline $18.8 \%$ & $53.1 \%$ & $25.0 \%$ & $3.1 \%$ & $1.6 \%$ & $1.6 \%$ & $29.7 \%$ & $67.2 \%$ \\
\hline \multicolumn{4}{|c|}{ Change } & & & & \\
\hline None & +1 & +2 & +3 & & & & \\
\hline $12.6 \%$ & $26.6 \%$ & $54.7 \%$ & $6.2 \%$ & & & & \\
\hline
\end{tabular}

Almost half of the respondents (44\%) initially gave themselves a two for their ability to formulate research questions/hypotheses and an additional 35\% gave themselves a three. The majority of respondents that responded with a two or three moved themselves up to a four by the 
end of their career. The difference was split ( $41 \%$ each) between one and two increments (Table 19).

Table 19: Formulate Research Questions/Hypotheses

\begin{tabular}{|c|c|c|c|c|c|c|c|}
\hline \multicolumn{4}{|c|}{ Started WVU } & \multicolumn{4}{|c|}{ Now } \\
\hline 1 (low) & 2 & 3 & 4 (high) & 1 (low) & 2 & 3 & 4 (low) \\
\hline $15.4 \%$ & $44.6 \%$ & $35.4 \%$ & $4.6 \%$ & $1.5 \%$ & $3.1 \%$ & $35.4 \%$ & $60.0 \%$ \\
\hline \multicolumn{4}{|c|}{ Change } & & & & \\
\hline $\begin{array}{c}\text { None } \\
15.3 \%\end{array}$ & $\begin{array}{c}+1 \\
41.5 \%\end{array}$ & $\begin{array}{c}+2 \\
41.5 \%\end{array}$ & $\begin{array}{c}+3 \\
1.5 \%\end{array}$ & & & & \\
\hline
\end{tabular}

When asked about their ability to search for research articles on a topic interest, $45 \%$ of respondents ranked themselves a two and 34\% ranking themselves as a three initially. The respondents usually moved to a four by the end of their careers at WVU (Table 20).

Table 20: Search for Research Articles on Topic of Interest

\begin{tabular}{|c|c|c|c|c|c|c|c|}
\hline \multicolumn{4}{|c|}{ Started WVU } & \multicolumn{4}{|c|}{ Now } \\
\hline 1 (low) & 2 & 3 & 4 (high) & 1 (low) & 2 & 3 & 4 (low) \\
\hline $13.8 \%$ & $44.6 \%$ & $33.8 \%$ & $7.7 \%$ & $1.5 \%$ & $1.5 \%$ & $35.4 \%$ & $61.5 \%$ \\
\hline \multicolumn{4}{|c|}{ Change } & & & & \\
\hline $\begin{array}{c}\text { None } \\
23.0 \%\end{array}$ & $\begin{array}{c}+1 \\
35.4 \%\end{array}$ & $\begin{array}{c}+2 \\
36.9 \%\end{array}$ & $\begin{array}{c}+3 \\
4.6 \%\end{array}$ & & & & \\
\hline
\end{tabular}

The initial rankings by the respondents were spread almost evenly between one (25\%), two (39\%), and three (32\%) for their ability to summarize research articles. The majority of the respondents for each of these categories ranked themselves with a four for their ending value. The most common differences were two and three with each occurring 34\% of the time (Table 21). 
Table 21: Summarize Research Articles

\begin{tabular}{|c|c|c|c|c|c|c|c|}
\hline \multicolumn{4}{|c|}{ Started WVU } & \multicolumn{4}{|c|}{ Now } \\
\hline 1 (low) & 2 & 3 & 4 (high) & 1 (low) & 2 & 3 & 4 (low) \\
\hline $24.6 \%$ & $38.5 \%$ & $32.3 \%$ & $4.6 \%$ & $1.5 \%$ & $4.6 \%$ & $40.0 \%$ & $53.8 \%$ \\
\hline \multicolumn{4}{|c|}{ Change } & & & & \\
\hline None & +1 & +2 & +3 & & & & \\
\hline $21.5 \%$ & $33.8 \%$ & $33.8 \%$ & $10.8 \%$ & & & & \\
\hline
\end{tabular}

The respondents were then asked about their ability to identify the strengths/limitations of different data collection methods. They most commonly ranked themselves either a one (36\%) or a two (45\%). Of the respondents that ranked themselves a one, $48 \%$ of them moved up to a three and of those that initially ranked themselves a two, $62 \%$ moved up to a four. This made the most common movement between rankings a plus two at 46\%. Results shown in Table 22.

Table 22: Identify the Strengths/Limitations of Different Data Collection Methods

\begin{tabular}{cccccccc}
\hline \multicolumn{3}{c}{ Started WVU } & \multicolumn{4}{c}{ Now } \\
\hline 1 (low) & 2 & 3 & 4 (high) & 1 (low) & 2 & 3 & 4 (low) \\
$35.9 \%$ & $45.3 \%$ & $17.2 \%$ & $1.6 \%$ & $1.6 \%$ & $10.9 \%$ & $37.5 \%$ & $50.0 \%$ \\
\hline \multicolumn{1}{c}{ Change } \\
\cline { 1 - 5 } None & +1 & +2 & +3 & & & & \\
$12.5 \%$ & $31.2 \%$ & $45.3 \%$ & $10.9 \%$ \\
\hline
\end{tabular}

When asked about their ability to identify ethical issues in social research, over half the respondents (55\%) initially ranked themselves at a two with the majority (59\%) moving up to a four by the end of their academic career. This once again made the most common movement a plus two at 42\%. Results shown in Table 23. 
Table 23: Identify Ethical Issues in Social Research

\begin{tabular}{cccccccc}
\hline \multicolumn{4}{c}{ Started WVU } & \multicolumn{4}{c}{ Now } \\
\cline { 1 - 5 } 1 (low) & 2 & 3 & 4 (high) & 1 (low) & 2 & 3 & 4 (low) \\
$23.1 \%$ & $55.4 \%$ & $21.5 \%$ & $0.0 \%$ & $1.5 \%$ & $4.6 \%$ & $36.9 \%$ & $56.9 \%$ \\
\hline \multicolumn{4}{c}{ Change } & & & & \\
\cline { 1 - 5 } None & +1 & +2 & +3 & & & & \\
$10.7 \%$ & $36.9 \%$ & $41.5 \%$ & $10.8 \%$ & & & &
\end{tabular}

The final question in the skills section asked respondents about their ability to write a research report that was understandable that was outside the field of sociology or anthropology. The most common initial ranking was a two at $42 \%$. These students most commonly moved up to a four (52\%). However, the most common movement was a plus one with $42 \%$ of respondents moving this way (Table 24).

Table 24: Write a Research Report that is Understandable by Non-Sociologist/Anthropologists

\begin{tabular}{|c|c|c|c|c|c|c|c|}
\hline \multicolumn{4}{|c|}{ Started WVU } & \multicolumn{4}{|c|}{ Now } \\
\hline 1 (low) & 2 & 3 & 4 (high) & 1 (low) & 2 & 3 & 4 (low) \\
\hline $26.6 \%$ & $4.2 \%$ & $26.6 \%$ & $4.7 \%$ & $1.6 \%$ & $6.2 \%$ & $35.9 \%$ & $56.2 \%$ \\
\hline \multicolumn{4}{|c|}{ Change } & & & & \\
\hline None & +1 & +2 & +3 & & & & \\
\hline $14.0 \%$ & $42.2 \%$ & $32.8 \%$ & $10.9 \%$ & & & & \\
\hline
\end{tabular}

The initial assessment measures set forth by the Division are an excellent starting point; however they must look at other assessment measures in order to continue with their student outcomes assessment. In order to help come up with methods that would be a successful fit for the Division, other sociology departments were looked at to see how they approach assessment, particularly student outcomes assessment. This will allow the department to determine what methods work best for in terms of direct measures. Some of the measures that other departments use would work for the Division; however some may need to be adjusted in order to work 
successfully or be feasible. There are four main outcomes assessment tools that other departments commonly utilize. They include the following: grading rubrics, portfolios, pre and post testing, and subject tests.

Grading rubrics are commonly used in advanced courses where students are usually in their senior year of a program. Grading rubrics are a tool that the department comes up with to grade writing assignments or oral presentations. The rubrics are usually in line with the student learning goals for that department and use a scale to determine how well students are using the skills that the department believes they should have learned sufficiently by the end of their time within a program.

The rubrics would be well utilized in the capstone courses within the Division. Even though some of the capstones within the Division cater to the different subjects that Division offers it can still be uniformed in a way. Items in the grading rubrics can be uniformed to address skills that the Division expects all their students to obtain. Then the Division can formulate specific items for Criminology and then Anthropology in the future once the Anthropology courses are expanded.

An example of a department that has used the Capstone course along with a grading rubric is the University of Wisconsin Milwaukee. This department like other departments sees the capstone experience course as a valuable course that allows students to expand on the knowledge that they have obtained throughout the rest of the program. In the case of this department, they use the research paper that all their students are required to complete for the course. The instructors then have five question assessments for each paper that is based off skills that the student should have demonstrated in their paper. An example of their capstone assessment can be found in Appendix B. 
The use of pre and post testing is another measurement that Division can utilize. Pre and Post testing is usually specific to particular courses. This form of assessment is usually used within introductory courses. However, this type of assessment measure does not need to be focused just on the big introductory classes. It can be utilized in the foundation courses or major requirement courses like Social Research Methods and Sociological Theory. There are many ways that pre and post testing can be formatted as well. It can be in the form of self assessment for the student. The faculty members can determine skills set that they believe the students should improve upon while in the course and then have the students do a self assessment at the beginning and end of the course and measure the change. Another way this can be done is have students take an actual test that deals with terms and theory. At the beginning of the term the students can be given a test, either multiple choice or written, that is based on terms and theories that the student will encounter during the course. The same test is then given at the end of the course. Then a comparison can be made between either the scores or how in depth the answers are depending on the type of test given.

The University of Minnesota Morris is an example of a department that uses pre and post testing. They utilize this technique in their introductory courses and in other courses that are used as prerequisites to more advanced courses. Each of the courses uses their own particular way of testing. Some of their courses like their introductory courses give the students a list of terms and have them define and also gives them the ability to provide examples. In other courses the instructors keeps track of how students change in the way they define particular terms, while other have the students respond to questions based on objectives and assesses the change in responses. This is only one way of using the pre and post testing method. It can also be used to 
test students when they come to WVU possibly when they take the orientation course and then again at the end during their capstone.

Some departments choose to have their graduating seniors take the Major Field Test for Sociology that is developed by ETS and then compare their results to the national data. The Major Field Test for Sociology contains nine subcategories: General Theory, Methodology and Statistics, Deviance and Social Problems, Demography, Multiculturalism, Social Institutions, Social Psychology, Gender, and Globalization. Even though this test covers a large range of areas and offers national comparison with other departments there are some drawbacks. First, the test takes two hours to complete. This means that it would take on average a little longer then a class meets for causing departments to have to find the time and place to administer the exam. Second, it only focuses on Sociology and even though it covers a broad range of areas under sociology a department with multiple majors is at a disadvantage.

Another assessment measure is the use of portfolios. The idea behind portfolios is simple. A collection of students' work is taken over the course of their time within a program and then viewed at the end to look for improvement. Portfolios can be an effective way to measure student outcomes, but like any measurement it has its drawbacks. First, if a department decides to use portfolios, it needs to be determined who is going to be responsible for keeping track of it. Some departments keep the portfolio, on file for the student requiring the students to bring items to be placed in the file. Other departments have the student keep track of their own portfolio and make it part of their requirement to graduate. Second, faculty must invest time to review each graduates portfolio usually making a rubric that will be used to assess the portfolios. This makes portfolios ideal for smaller departments. Below are descriptions of three departments that use portfolios for assessment. Each of these departments handles the portfolios differently. 
Northern Kentucky University, University of Wisconsin, and Willamette University are all examples of sociology departments that use portfolios as part of their assessment and all of them have their own way of handling them. Northern Kentucky University requires all of their seniors to submit a portfolio as part of their Senior Seminar course. The students must submit five assignments that they believe have encompassed the five learning goals that the department has

outlined. The University of Wisconsin-Superior takes a slightly different approach to portfolios. The department takes on the responsibility of keeping the portfolios on file for the student. During each advisement session, students are expected to answer five self assessment questions before hand that are based on the departments learning objectives. The student must also bring with them work they think is relevant to those goals to be placed into their portfolio. The student and the faculty work together to get to the finished portfolio and discuss how the student feels he/she is progressing through the program. Finally, Willamette University also uses portfolios as a way of assessment. Willamette University has each of their students submit a portfolio their senior year. They require the student to include five papers from a list of courses the student would have taken. Included with each of the papers they require the student to assess their work by describing the strengths and weaknesses of each paper. The portfolios are then evaluated by faculty members at the end of the year.

\section{Conclusions and Recommendations}

Assessment is at the core of any organization. In order for the Division of Sociology and Anthropology to continue to be successful in years to come, it needs to make sure to continue with its assessment process and continually look back on what they have done and where they are going. The current assessment process provides insights on areas that the department needs to improve upon and also the ability to look towards future assessment. 
Based on the current assessment results there were some core findings that came about in almost all of them. First, both alumni and graduating seniors were somewhat unhappy about advising within the Division. The Division has already taken steps to improve this by bringing in pre-majors to be advised. However, the Division might want to consider making sure that every advisor is willing to setup individual meetings for students that may want one on one advising instead of group advising. It is not reasonable to only do one on one advising, because of the sheer numbers of majors and pre-majors; however students should be given the option. There may be ways to make improvements to group advising so that students feel they are getting individual attention. First, group advising could be limited to about 5 students per meeting. Then instead of just checking off on the student's schedule the advisor needs to make sure that they ask the students if they have any questions regarding their schedules. If they do not have any questions at the time of their advisement then make them aware that they can contact their advisor if they have any questions in the future. This might make the students feel like the faculty see them as an individual not just a number.

Another one of the concerns from students was that the internship program needs improvement. Students should be made aware of internships well in advance and be advised more on the opportunities in the surrounding areas and how to gain access to federal programs. This can be done by discussing internships during advising or in courses like SOCA 199. This way the students are aware of the time it takes to get into an internship and the competition involved in gaining spots.

Also the Division needs to be concerned that the majority of their students are only passing with a C. Statistical analysis is an important part of quantitative analysis and the Division should want their students to understand it the best they can. Based on the information from the 
transcript analysis, most students are passing their statistics courses with the minimum required grade. However, the Division should consider bringing statistics into the department. The students will then be exposed to how statistics are used in social research and they will receive a more hands on experience with it

In terms of future assessment, there are improvements that can be made to the current assessment measures and additional measures can and should be added. First, alumni surveys need to be administered at least every three to four years in order to keep track of what the alumni are doing and if improvements that are being made are actually working. Second, the graduating senior surveys need to be administered better. The ones for this assessment were administered late and as a result, the response rate may have been negatively affected. There are some improvements that can be made in the future to better this process. The senior surveys should be administered annually to students that will be graduating that term via an online survey, such as Survey Monkey. They should also be done in during the fall, spring, and summer semesters of each academic year.

In terms of new assessment, I would suggest the use of the capstone course. Papers are written by every student that is enrolled in a capstone course. These papers should either be graded using a set rubric or have the faculty fill out an additional questionnaire for each paper that has questions regarding set skills that a student should have acquired and should be present in a higher level paper. Since there are so many students that complete a capstone every semester it this process may be more manageable if five or so papers are chosen at random from each capstone course. The questions or rubrics should be agreed upon by the faculty as a whole. Another suggestion would be to maybe set up a committee that would be in charge of assessing the papers and each paper is assessed multiple times for validity. 
The Division might want to consider the Major Field Test as an option for future assessment. This would give the Division the ability to compare their majors to other Sociology majors across the nation. Also, the Division would be able to add additional questions specifically to evaluate their learning objectives. However, as stated previously the test can be expensive depending on how many tests need to be ordered. This test would also be something that the students would have to do outside of class and could be difficult. However, if the test is required for graduation it might be able to easily get around this drawback. Through ongoing assessment of student outcomes and curriculum the Division of Sociology and Anthropology should be able to continue to improve and meet the needs of their students.

\section{Post Script}

On a Saturday in February of 2009 the results from the transcript analysis and the graduating senior surveys were presented to faculty at an all day retreat. After the results were presented there was a discussion on what they mean for the Division, which was presented in this paper. Towards, the last portion of the retreat's discussion was focused on how the Division should move forward in terms of direct measures for the assessment.

At a previous retreat it was suggested to use the capstone experience as a way to directly assess the students through the use of the final project/paper. It was brought up at the retreat that a rubric for the final project/paper is the norm when it comes to using the capstone project and it was met with apprehension. One of the concerns had to with the fact that the Division is so diverse and that it offers capstones in Criminology, Sociology, and Anthropology and each professor that teaches the course handles the final project differently. This caused the faculty members to become defensive; because they felt that the Division was trying to not only dictate how they conducted their class, but how they grade their papers. It was assured to them that it 
was not going to be how it was used, but despite the efforts of the two main faculty members working on assessment it was pushed to the side to be discussed at a later time.

The floor was then opened up for suggestions for other ways to directly measure outcomes. A lot of the faculty liked the idea of final cumulative tests for each of the different majors for students to take before they graduate. However, this too was met with conflict. First, the Anthropologists pointed out this type of measure would not work for their students, because of more applied skills that they learn. Also even though many thought this was a great idea no one wanted to step up and help with it, which comes back to the point that faculty must be invested in assessment.

It was clear during all the disagreements that the faculty were in line with the literature in terms of why faculty resist assessment. Some saw it as a bureaucratic measure that was passed down from above to justify their work. Others thought it was time consuming and did not want to give it a chance, because of their already busy lives. The Division not only has a large number of students, but also faculty and without support from all sides assessment will be difficult to complete. Faculty need to buy into the idea that assessment in general is beneficial to the Division and not just a way to get more funding. Assessment gives faculty a chance to see how they are doing and to see that they are successful in terms of professors. When students are able to go on and get jobs or get into other graduate programs it is directly related to how well they were prepared within their major. The retreat highlighted that how the Division moves forward with the assessment process has as much to do with its ability to obtain broader acceptance of the process as with the technical and logistical considerations highlighted in this thesis. 


\section{References}

Abromeit, Jeana and Stephen R. Sharkey. 2001. "Bringing Student Self Assessment into the Sociology Curriculum.” Pp: 138-163 in Assessing Student Learning in Sociology $2^{\text {nd }}$ Edition. Edited by Charles F. Hohm and William Johnson. Washington, DC: American Sociological Association.

American Association for Higher Learning. 2001. "Nine Principles of Good Assessment of Student Learning.” Pp: 220-221 in Assessing Student Learning in Sociology $2^{\text {nd }}$ Edition. Edited by Charles f. Hohm and William Johnson. Washington, DC: American Sociological Association.

Banta, Trudy W. 2001. “Assessing Competence in Higher Education.” Pp: 1-12 in Assessing Student Competence in Accredited Disciplines, edited by Catherine A. Palomba and Trudy W. Banta. Sterling, VA: Stylus Publishing.

Berheide, Catherine White. 2001. "Using the Capstone Course for Assessment of Learning in the Sociology Major.” Pp: 164- 176 in Assessing Student Learning in Sociology $2^{\text {nd }}$ Edition. Edited by Charles F. Hohm and William Johnson. Washington, DC : American Sociological Association.

Cappell, Charles L. and David H. Kamens. 2002. "Curriculum Assessment: A Case Study in Sociology.” Teaching Sociology 30(4):467-494.

Division of Sociology \& Anthropology: WVU. 2008. “Mission Statement.” West Virginia University, Retrieved October 13, 2008 (http://www.as.wvu.edu/SOCA/futurestudents/missionstatement.htm).

Division of Sociology and Anthropology, West Virginia University. 2008 Assessment Report submitted to the Eberly College of Arts of Sciences, March.

Dorn, Dean S. “An Electronic Assessment Portfolio at California State University-Sacramento.” Pp: 94121 in Assessing Student Learning in Sociology $2^{\text {nd }}$ Edition. Edited by Charles F. Hohand William Johnson. Washington, DC: American Sociological Association.

Eck, Beth A., William S. Johnson, and Mary Lou Wylie. 2001. “Overview of Assessment Issues.” Pp: 10-13 in Assessing Student Learning in Sociology $2^{\text {nd }}$ Edition. Edited by Charles F. Hohm and William Johnson. Washington, DC: American Sociological Association.

Educational Testing Services. 2009. “Major Field Tests: End of program outcomes assessment.” ETS, Retrieved February 04, 2009.

(http://www.ets.org).

Hohm, Charles F. 2001. “What Do We Mean by Assessment?” Pp: 178 -179 in Assessing Student Learning in Sociology $2^{\text {nd }}$ Edition. Edited by Charles F. Hohm and William Johnson. Washington, DC: American Sociological Association. 
Hohm, Charles F. and William S. Johnson. 2001. "A System-Wide Approach to Assessing Student Learning in Sociology.” Pp: 50- 58 in Assessing Student Learning in Sociology $2^{\text {nd }}$ Edition. Edited by Charles F. Hohm and William Johnson. Washington, DC: American Sociological Association.

Hood, Denice Ward, Shelly Keimig Potts, and William S. Johnson. 2001. “General Guidelines for Designing and Implementing a Departmental Learning Outcomes Assessement.” Pp: 73-93 in Assessing Student Learning in Sociology $2^{\text {nd }}$ Edition. Edited by Charles F. Hohm and William Johnson. Washington, DC: American Sociological Association.

Howery, Carla B. 2001. “Assessment: It's the Right Thing to Do.” Pp: 4-9 in Assessing Student Learning in Sociology $2^{\text {nd }}$ Edition. Edited by Charles F. Hohm and William Johnson. Washington, DC: American Sociological Association.

Jones, Carolee G. 1999. "The Portfolio as a Course Assessment Tool Case 66: Ball State University.” Pp: 285-288 in Assessment in Practice: Putting Principles to Work on College Campuses. Edited by Trudy W. Banta, Jon P. Lund, Karen E. Black, and Frances W. Olblander. San Francisco: Jossey-Bass Publishers.

Northern Kentucky University. 2008. "Senior Portfolio: Department of Sociology, Anthropology, \& Philosophy.” Highland Heights, KY: Northern Kentucky University, Retrieved February 04, 2009

(http://sap.nku.edu/sociology/srportfolio.php)

O’Brien, Paul W., Agnes C. Reidmann, Walter E. Doraz, and James T. Payne. 2001. “Assessing Student Perceptions: Neglected Voices in Departmental Assessment.” Pp: 59-71 in Assessing Student Learning in Sociology $2^{\text {nd }}$ Edition. Edited by Charles F. Hohm and William Johnson. Washington, DC: American Sociological Association.

Palomba, Catherine A. and Trudy W. Banta. 1999. Assessment Essentials. San Francisco, CA: JosseyBass.

Palomba, A. Catherine. 2001. "Implementing Effective Assessment.” Pp: 13-28 in Assessing Student Competence in Accredited Disciplines, edited by Catherine A. Palomba and Trudy W. Banta. Sterling, VA: Stylus Publishing.

Senter, Mary Scheuer. 2001. “Academic Outcomes Assessment: Fads, Fallacies, and Footsteps.” Pp: 14 -25 in Assessing Student Learning in Sociology $2^{\text {nd }}$ Edition. Edited by Charles F. Hohm and William Johnson. Washington, DC: American Sociological Association.

Trepagnier, Barbara. 2004. “Teaching Sociology through Student Portfolios.” Teaching Sociology 32(2):197-205. 
University of Minnesota Morris. 2007. “Sociology Discipline Assessment 2006 - 2007.” Morris, MN: University of Minnesota Morris, Retrieved February 03, 2009 (http://www.morris.umn.edu/committees/asl/results/Soc2007.html).

University of Wisconsin Milwaukee. "Assessment of Undergraduate and Graduate Programs in Sociology.” Milwaukee, WI: University of Wisconsin Milwaukee, Retrieved February 03, 2009 (http://www.uwm.edu/letsci/abvssessplans/SociolAssess.pdf).

University of Wisconsin-Superior. "Social Inquiry Department: Portfolio Assessment.” Superior,WI: University of Wisconsin-Superior, Retrieved February 04, 2008. (http://www.uwsuper.edu/acaddept/si/sociology/portfolio.cfm).

Wagenaar, Theodore C. 1993. “The Capstone Course.” Teaching Sociology 21(3):209-214.

Wagenaar, Theodore C. 2002. “Outcomes Assessment in Sociology: Prevalence and Impact.” Teaching Sociology 30(4):403-413.

Weiss, Gregory L., Janet R. Crosbey, Shelly K. Habel, Chad M. Hanson, and Carolee Larson. 2002. "Improving the Assessment of Student Learning: Advancing a Research Agenda in Sociology." Teaching Sociology 30: 63- 79.

Willamette University. 2008. "Sociology: Student Portfolio Requirement.” Salem, Oregon: Willamette University, Retrieved February, 042009. (http://www.willamette.edu/cla/sociology/portfolio/index.php).

Wolfer, Loreen. 2007. Real Research: Conducting and Evaluating Research in the Social Sciences. Boston, MA: Pearson Education, Inc. 


\section{Appendix A}

Tables and Cross Tabulations for Graduating Senior Surveys Self Assessment 
Convey the benefits of sociological/anthropological training to a potential employer

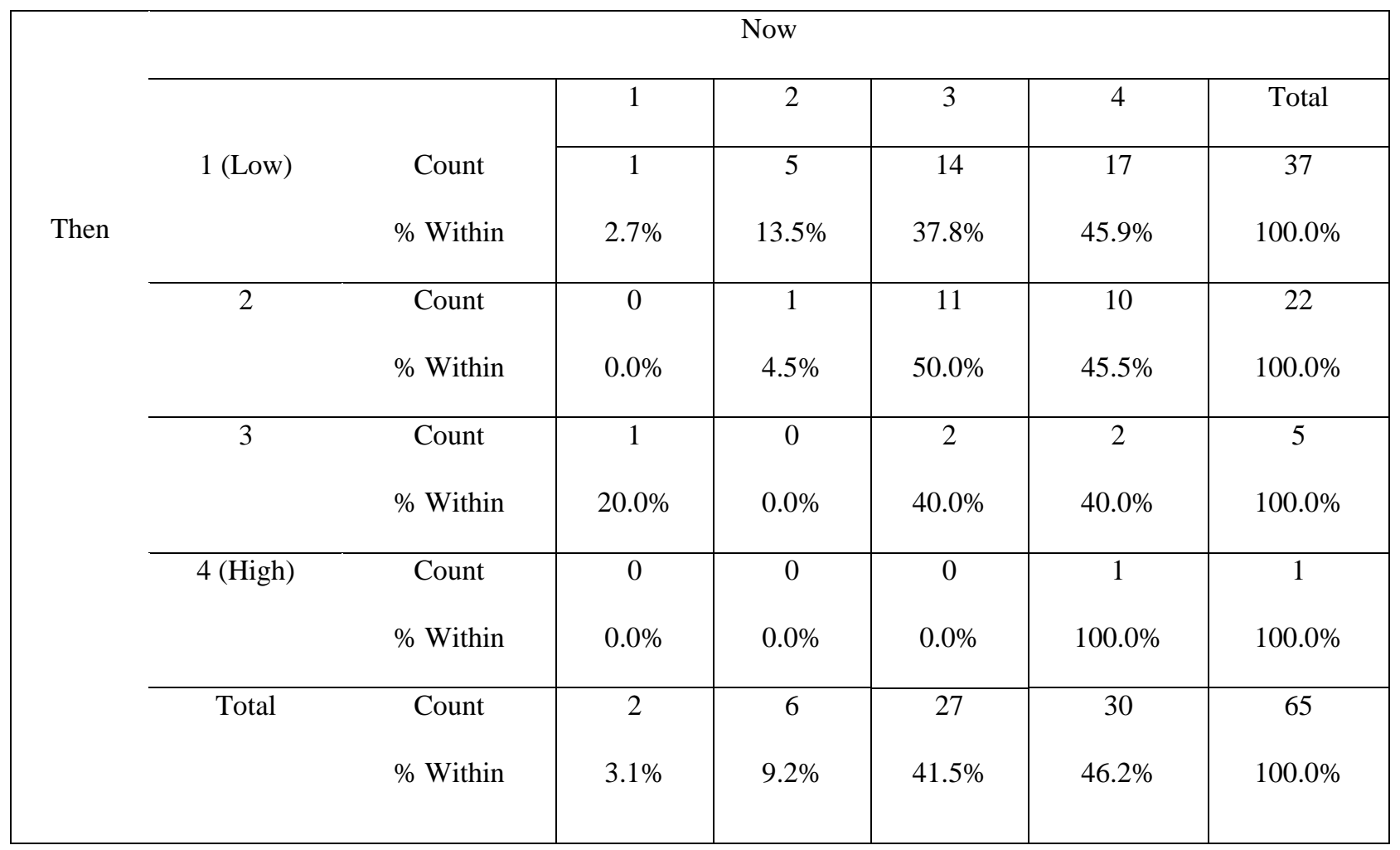

Distinguish empirical generalizations from stereotypes

\begin{tabular}{|c|c|c|c|c|c|c|c|}
\hline & \multicolumn{7}{|c|}{ Now } \\
\hline & & & 1 & 2 & 3 & 4 & Total \\
\hline & 1 (Low) & Count & 0 & 0 & 8 & 4 & 12 \\
\hline \multirow[t]{9}{*}{ Then } & & \% Within & $0.0 \%$ & $0.0 \%$ & $66.7 \%$ & $33.3 \%$ & $100.0 \%$ \\
\hline & 2 & Count & 0 & 0 & 7 & 27 & 34 \\
\hline & & \% Within & $0.0 \%$ & $0.0 \%$ & $20.6 \%$ & $79.4 \%$ & $100.0 \%$ \\
\hline & 3 & Count & 1 & 1 & 4 & 10 & 16 \\
\hline & & \% Within & $6.2 \%$ & $6.2 \%$ & $25.0 \%$ & $62.5 \%$ & $100.0 \%$ \\
\hline & 4 (High) & Count & 0 & 0 & 0 & 2 & 2 \\
\hline & & \% Within & $0.0 \%$ & $0.0 \%$ & $0.0 \%$ & $100.0 \%$ & $100.0 \%$ \\
\hline & Total & Count & 1 & 1 & 19 & 43 & 64 \\
\hline & & \% Within & $1.6 \%$ & $1.6 \%$ & $29.7 \%$ & $67.2 \%$ & $100.0 \%$ \\
\hline
\end{tabular}


Formulate research questions/hypotheses

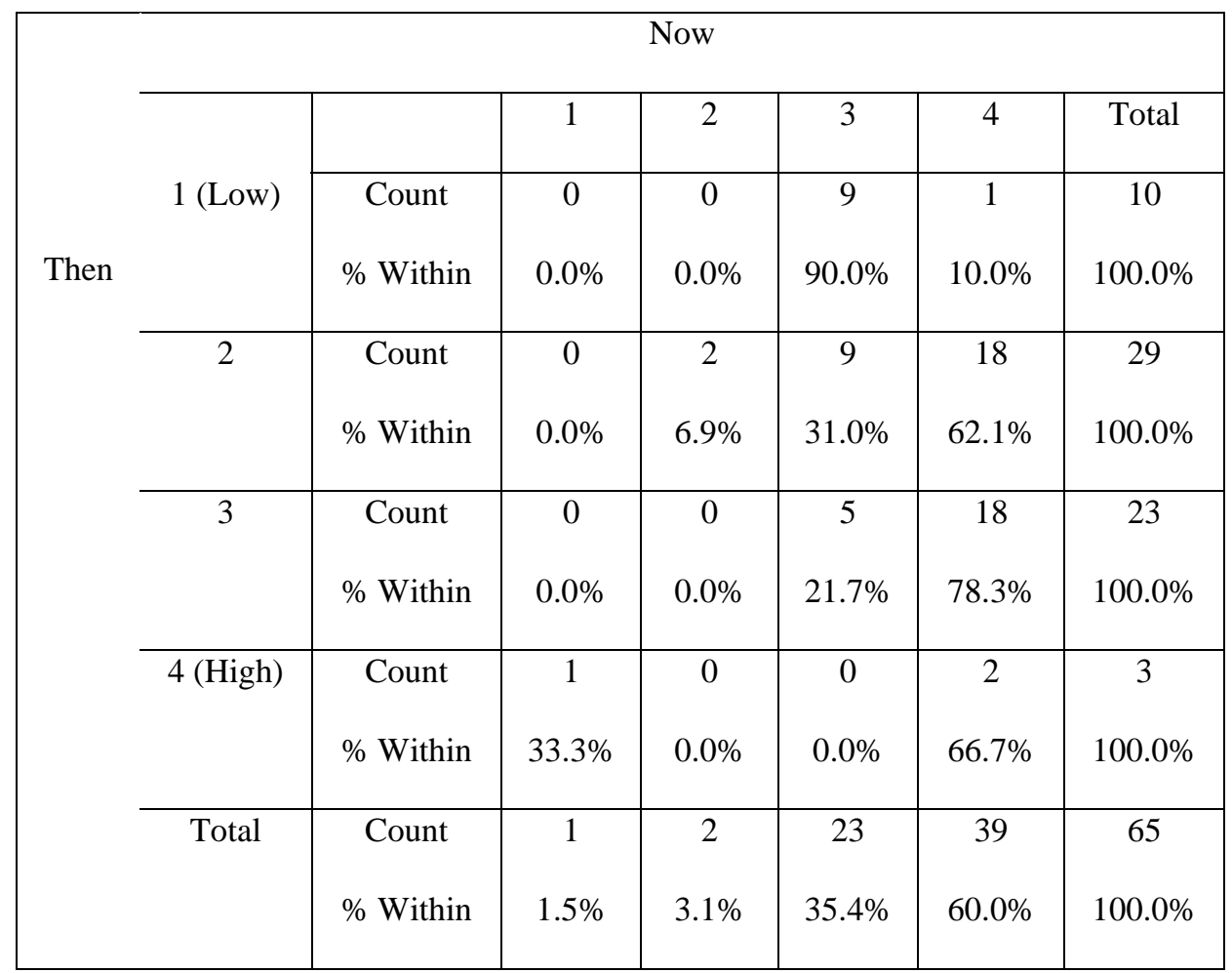

Search for research articles on a topic of interest

\begin{tabular}{|c|c|c|c|c|c|c|c|}
\hline & & & & Now & & & \\
\hline & & & 1 & 2 & 3 & 4 & Total \\
\hline & 1 (Low) & Count & 0 & 0 & 6 & 3 & 9 \\
\hline Then & & \% Within & $0.0 \%$ & $0.0 \%$ & $66.7 \%$ & $33.3 \%$ & $100.0 \%$ \\
\hline & 2 & Count & 1 & 1 & 9 & 18 & 29 \\
\hline & & \% Within & $3.4 \%$ & $3.4 \%$ & $31.0 \%$ & $62.1 \%$ & $100.0 \%$ \\
\hline & 3 & Count & 0 & 0 & 8 & 14 & 22 \\
\hline & & \% Within & $0.0 \%$ & $0.0 \%$ & $36.4 \%$ & $63.6 \%$ & $100.0 \%$ \\
\hline & 4 (High) & Count & 0 & 0 & 0 & 5 & 5 \\
\hline & & \% Within & $0.0 \%$ & $0.0 \%$ & $0.0 \%$ & $100.0 \%$ & $100.0 \%$ \\
\hline & Total & Count & 1 & 1 & 23 & 40 & 65 \\
\hline & & \% Within & $1.5 \%$ & $1.5 \%$ & $35.4 \%$ & $61.5 \%$ & $100.0 \%$ \\
\hline
\end{tabular}


Summarize research articles

\begin{tabular}{|c|c|c|c|c|c|c|c|}
\hline & & & & Tow & & & \\
\hline & & & 1 & 2 & 3 & 4 & Total \\
\hline & 1 (Low) & Count & 0 & 1 & 8 & 7 & 16 \\
\hline Then & & \% Within & $0.0 \%$ & $6.2 \%$ & $50.0 \%$ & $43.8 \%$ & $100.0 \%$ \\
\hline & 2 & Count & 0 & 2 & 9 & 14 & 25 \\
\hline & & \% Within & $0.0 \%$ & $8.0 \%$ & $36.0 \%$ & $56.0 \%$ & $100.0 \%$ \\
\hline & 3 & Count & 0 & 0 & 9 & 12 & 21 \\
\hline & & \% Within & $0.0 \%$ & $0.0 \%$ & $42.9 \%$ & $57.1 \%$ & $100.0 \%$ \\
\hline & 4 (High) & Count & 1 & 0 & 0 & 2 & 3 \\
\hline & & \% Within & $33.3 \%$ & $0.0 \%$ & $0.0 \%$ & $66.7 \%$ & $100.0 \%$ \\
\hline & Total & Count & 1 & 3 & 26 & 35 & 65 \\
\hline & & \% Within & $1.5 \%$ & $4.6 \%$ & $40.0 \%$ & $53.8 \%$ & $100.0 \%$ \\
\hline
\end{tabular}

Identify the strengths and limitations of different data collection methods

\begin{tabular}{|c|c|c|c|c|c|c|c|}
\hline & & & & Now & & & \\
\hline & & & 1 & 2 & 3 & 4 & Total \\
\hline & 1 (Low) & Count & 0 & 5 & 11 & 7 & 23 \\
\hline Then & & \% Within & 0.0 & $21.7 \%$ & $47.8 \%$ & $30.4 \%$ & $100.0 \%$ \\
\hline & 2 & Count & 0 & 2 & 9 & 18 & 29 \\
\hline & & \% Within & $0.0 \%$ & $6.9 \%$ & $31.0 \%$ & $62.1 \%$ & $100.0 \%$ \\
\hline & 3 & Count & 1 & 0 & 4 & 6 & 11 \\
\hline & & \% Within & $9.1 \%$ & $0.0 \%$ & $36.4 \%$ & $54.5 \%$ & $100.0 \%$ \\
\hline & 4 (High) & Count & 0 & 0 & 0 & 1 & 1 \\
\hline & & \% Within & $0.0 \%$ & $0.0 \%$ & $0.0 \%$ & $100.0 \%$ & $100.0 \%$ \\
\hline & Total & Count & 1 & 7 & 24 & 32 & 64 \\
\hline
\end{tabular}




\begin{tabular}{|l|l|l|l|l|l|l|}
\hline & \% Within & $1.6 \%$ & $10.9 \%$ & $37.5 \%$ & $50.0 \%$ & $100.0 \%$ \\
\hline
\end{tabular}

Identify ethical issues in social research

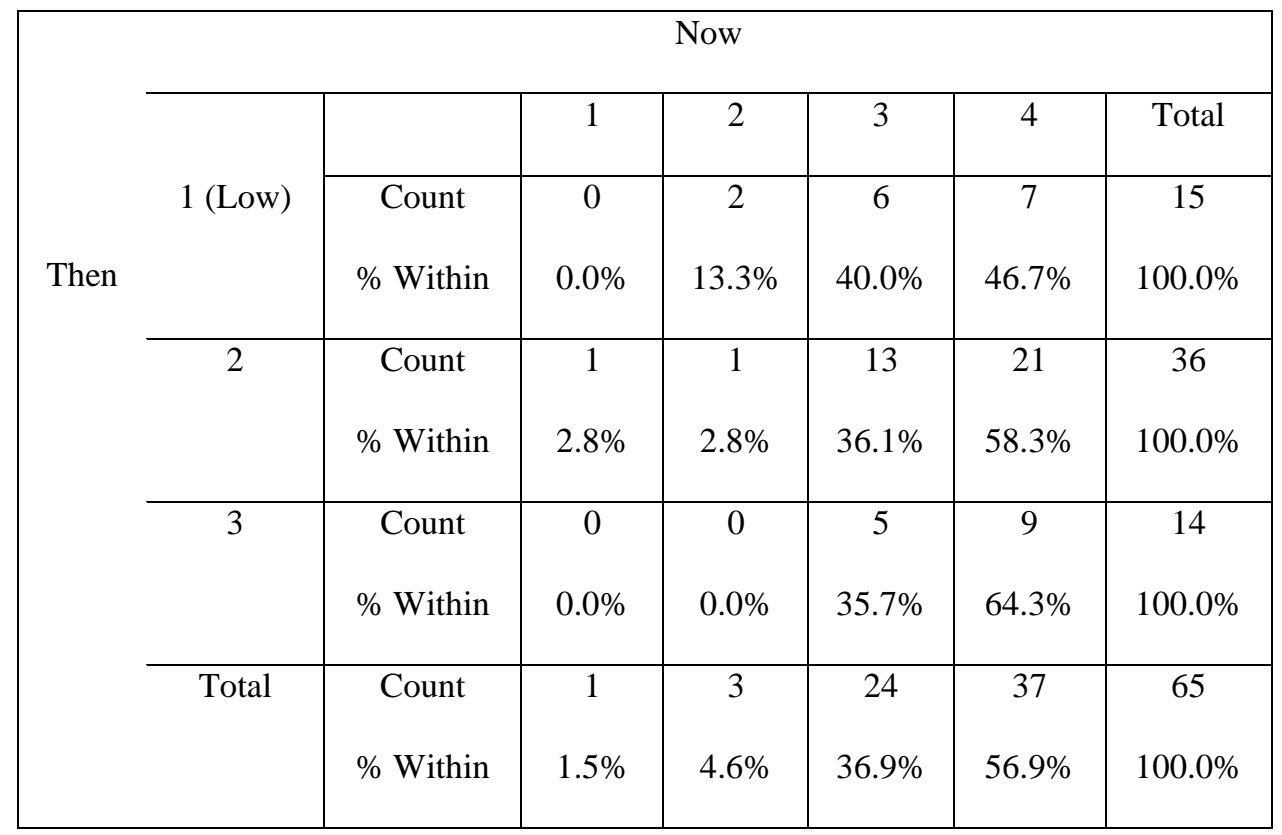

Write a research report that is understandable by non-sociologists/anthropologists

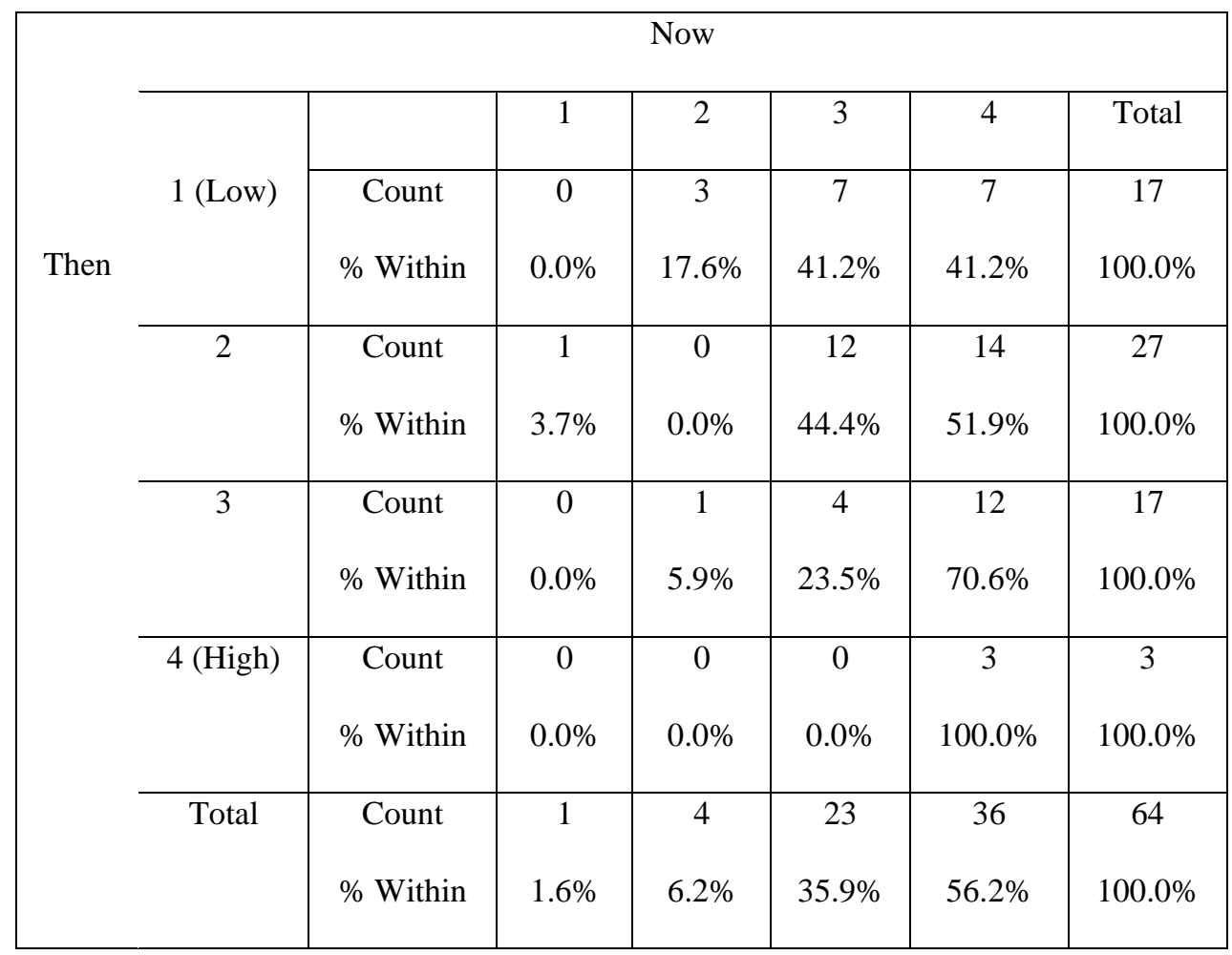


Appendix B

Capstone Rubric 


\begin{tabular}{|c|l|l|l|l|l|}
\hline & $\begin{array}{c}\text { Strongly } \\
\text { Agree }\end{array}$ & Agree & Neither & Disagree & Strongly Disagree \\
\hline $\begin{array}{c}\text { The student can frame a } \\
\text { problem or issue in a } \\
\text { sociological context }\end{array}$ & & & & & \\
\hline $\begin{array}{c}\text { The student can employ } \\
\text { and evaluate sociological } \\
\text { theories and concepts } \\
\text { when presenting an issue. }\end{array}$ & & & & & \\
\hline $\begin{array}{c}\text { The student can analyze } \\
\text { sociological data and can } \\
\text { interpret research findings }\end{array}$ & & & & & \\
\hline $\begin{array}{c}\text { The student can develop } \\
\text { an appropriate research } \\
\text { plan for a sociological } \\
\text { investigation, including } \\
\text { the use of an appropriate } \\
\text { methodology if collecting } \\
\text { data }\end{array}$ & & & & & \\
\hline $\begin{array}{c}\text { The student can write a } \\
\text { scholarly sociology paper } \\
\text { that is organized and } \\
\text { coherent. }\end{array}$ & & & & & \\
\hline
\end{tabular}

